\title{
Tracer-based analysis of spatial and temporal variations of water sources in a glacierized catchment
}

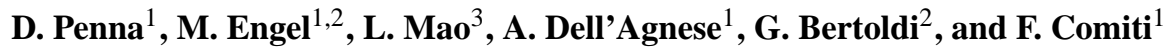 \\ ${ }^{1}$ Faculty of Science and Technology, Free University of Bozen-Bolzano, piazza Università 5, 39100 Bolzano, Italy \\ ${ }^{2}$ Institute for Alpine Environment, EURAC, viale Druso 1, Bozen-Bolzano, Italy \\ ${ }^{3}$ Department of Ecosystems and Environment, Pontificia Universidad Católica de Chile, Av. Vicuña Mackenna 4860, \\ Macul, Casilla 306-22, Santiago, Chile \\ Correspondence to: D. Penna (daniele.penna@unibz.it)
}

Received: 17 April 2014 - Published in Hydrol. Earth Syst. Sci. Discuss.: 15 May 2014

Revised: 14 October 2014 - Accepted: 20 November 2014 - Published: 17 December 2014

\begin{abstract}
Snow-dominated and glacierized catchments are important sources of fresh water for biological communities and for populations living in mountain valleys. Gaining a better understanding of the runoff origin and of the hydrological interactions between meltwater, streamflow and groundwater is critical for natural risk assessment and mitigation as well as for effective water resource management in mountain regions. This study is based on the use of stable isotopes of water and electrical conductivity as tracers to identify the water sources for runoff and groundwater and their seasonal variability in a glacierized catchment in the Italian Alps. Samples were collected from rainfall, snow, snowmelt, ice melt, spring and stream water (from the main stream at different locations and from selected tributaries) in 2011, 2012 and 2013. The tracer-based mixing analysis revealed that, overall, snowmelt and glacier melt were the most important endmembers for stream runoff during late spring, summer and early fall. The temporal variability of the tracer concentration suggested that stream water was dominated by snowmelt at the beginning of the melting season (May-June), by a mixture of snowmelt and glacier melt during mid-summer (Julyearly August), and by glacier melt during the end of the summer (end of August-September). The same seasonal pattern observed in streamflow was also evident for groundwater, with the highest electrical conductivity and least negative isotopic values found during cold or relatively less warm periods, when the melt of snowpack and ice was limited. Particularly, the application of a two-component mixing model to data from different springs showed that the snowmelt contribution to groundwater recharge varied between $21 \%( \pm 3 \%)$
\end{abstract}

and $93 \%( \pm 1 \%)$ over the season, and the overall contribution during the three study years ranged between $58 \%$ $( \pm 24 \%)$ and $72 \%( \pm 19 \%)$. These results provided new insights into the isotopic characterization of the study catchment presenting further understanding of the spatio-temporal variability of the main water sources contributing to runoff.

\section{Introduction}

High-elevation mountain catchments are environments of highly economic and social value since they store large volumes of water in the form of snow and ice bodies and release it on a seasonal basis as meltwater. Large populations living downstream of glacierized catchments primarily rely on snow and glacier meltwater for drinking and irrigation needs (Kriegel et al., 2013). Meltwater also plays an important role in the aquatic ecology of downstream reaches, because it regulates summer stream temperatures, maintaining high-quality habitat for fish and cold-water communities (Grah and Beaulieu, 2013). From a hydrological perspective, snowmelt and glacier melt are important because they moderate inter-annual variability in streamflow (Stewart, 2009), and can maintain elevated discharge during the dry season or relatively dry years (Milner et al., 2009) when water demand is highest.

High-elevation catchments are complex environmental systems where different water sources interact to affect the streamflow regime and the geochemical composition of stream water. Understanding such a complexity is a first step 
towards a better conceptualization of catchment functioning that is essential for natural risk assessment and mitigation as well as for effective water resource management in mountain regions. This is made more critical due to the current changing climatic conditions, to which snow-dominated and glacierized environments are particularly vulnerable. The expected future retreat of mountain glaciers and earlier melt of snowpack is producing marked effects on the water balance. In future, mean annual runoff is expected to decrease but peak runoff is likely to increase (Molini et al., 2011), with seasonal shifts in the runoff regime (Kääb et al., 2007) and in the relative timing and contribution of the different water sources to baseflow, peak flow and groundwater. This raises major concerns about water supply security in mountain regions (Uhlmann et al., 2013).

In order to better predict future hydrological behaviour in such rapidly changing environments there is an urgent need to obtain a more detailed understanding of runoff origin and the dynamic interactions between meltwater and streamflow in glacierized catchments. A powerful investigation tool useful for this purpose is represented by tracers. Particularly, the stable isotopes of water $\left(\delta^{2} \mathrm{H}\right.$ and $\left.\delta^{18} \mathrm{O}\right)$ have been recently used in high-elevation catchments to quantify post-snowmelt summer rainfall contributions to streamflow (Dahlke et al., 2013), estimate the regional water balance (Ohlanders et al., 2013), compute catchment residence times (Jeelani et al., 2013; Chiogna et al., 2014) and constrain model parameters (Cable et al., 2011). Moreover, water isotopes, coupled to other geochemical tracers, such as electrical conductivity (EC), have the potential to identify end-members (i.e. the dominant sources to runoff) and compute their contribution to streamflow (Maurya et al., 2011).

The water input due to snow and glacier meltwater during spring and summer is relevant for the yearly runoff regime of streams and groundwater in high-elevation Alpine areas (Koboltschnig and Schöner, 2011). Particularly, inner valleys of the Alps are characterized by relatively low amounts of liquid precipitation and significantly benefit from the water contribution provided by lateral valleys where snowmelt and/or glacier melt dominate streamflow and feed groundwater. One clear example is given by the Vinschgau/Venosta valley, in South Tyrol (Eastern Italian Alps), where most of the economy is based on the cultivation of apples. Since here the climate is relatively dry (the mean annual precipitation for the period 1989-2012 in Laas-Lasa, at $863 \mathrm{~m}$ a.s.l. was $480 \mathrm{~mm}$ ) a large part of water supply derives from stream water from the tributaries of the main valley, which are used for pressurized irrigation and hydropower production. Given the socio-economic importance of meltwater in this region, we conducted an experimental research in the glacierized Saldur catchment, one of the catchments that contributes to water availability in the upper Vinschgau valley. Importantly, the glacier in the Saldur catchment is melting at a particularly fast rate, with $20 \%$ of areal reduction from 2005 to 2013 (Galos and Kaser, 2014). The Saldur catchment has recently been the subject of different hydrological studies (e.g. Bertoldi et al., 2014; Della Chiesa et al., 2014; Pasolli et al., 2014) but an assessment of the runoff water sources and of their spatiotemporal variability based on an isotopic characterization of the catchment is still lacking.

In this paper, we take advantage of the combined use of two tracers, namely stable isotopes of water and EC, sampled from precipitation and different water bodies over three consecutive years, to

1. define the origin of vapour masses that form precipitation in the study area

2. identify the end-members to streamflow

3. understand the seasonal variability of tracer concentration in stream water and groundwater

4. quantify the role of snowmelt on groundwater recharge.

\section{Study area}

The field activities were carried out in the upper Saldur/Saldura catchment $\left(61.7 \mathrm{~km}^{2}\right)$ located in the upper Vinschgau/Venosta valley, South Tyrol (Eastern Italian Alps). Elevations in the catchment range from $1.632 \mathrm{~m}$ a.s.l. at the outlet - chosen at a gauging station upstream of the confluence with the Etsch/Adige River - to $3.725 \mathrm{~m}$ a.s.l. of the highest peak (Weißkugel/Palla Bianca). The upper part of the catchment hosts the Matsch/Mazia glacier (extent of $2.2 \mathrm{~km}^{2}$ in 2013, Galos and Kaser, 2014) whose current snout lies approximately at $2800 \mathrm{~m}$ a.s.l. and feeds the Saldur River. Downstream of the glacier snout, the Saldur River receives water contributions from various tributaries, most of them especially on the left side of the valley, originating at elevations above $2900 \mathrm{~m}$ a.s.l. and therefore snow-covered approximately from October/November to May/June. As such, streamflow during summer and part of spring and fall is noticeably affected by water inputs mainly deriving from melting of the glacier body and the winter snowpack in different portions of the catchment. Glacier erosion formed the typical U-shape in the upper valley that is partly filled with sediment from talus, small shallow landslides and large alluvial/debris fans from the steep tributaries. The average slope of the catchment is $31.8^{\circ}$ and the aspect is predominantly towards the south (Fig. 1 and Table 1).

The study area has a continental climate with low total annual precipitation compared to other mountain areas at the same elevation. At $1570 \mathrm{~m}$ a.s.l., where a weather station is run by the Province of Bozen-Bolzano, the mean annual air temperature is $6.6^{\circ} \mathrm{C}$ and the mean annual precipitation is $569 \mathrm{~mm} \mathrm{yr}^{-1}$. The latter is estimated to increase up to $800-$ $1000 \mathrm{~mm} \mathrm{yr}^{-1}$ at $2000 \mathrm{~m}$ a.s.l. Precipitation typically occurs as snowfall from November to late April, while summer precipitation mainly originates from convective rainfall events. However, snow storms can also occur during the summer at 


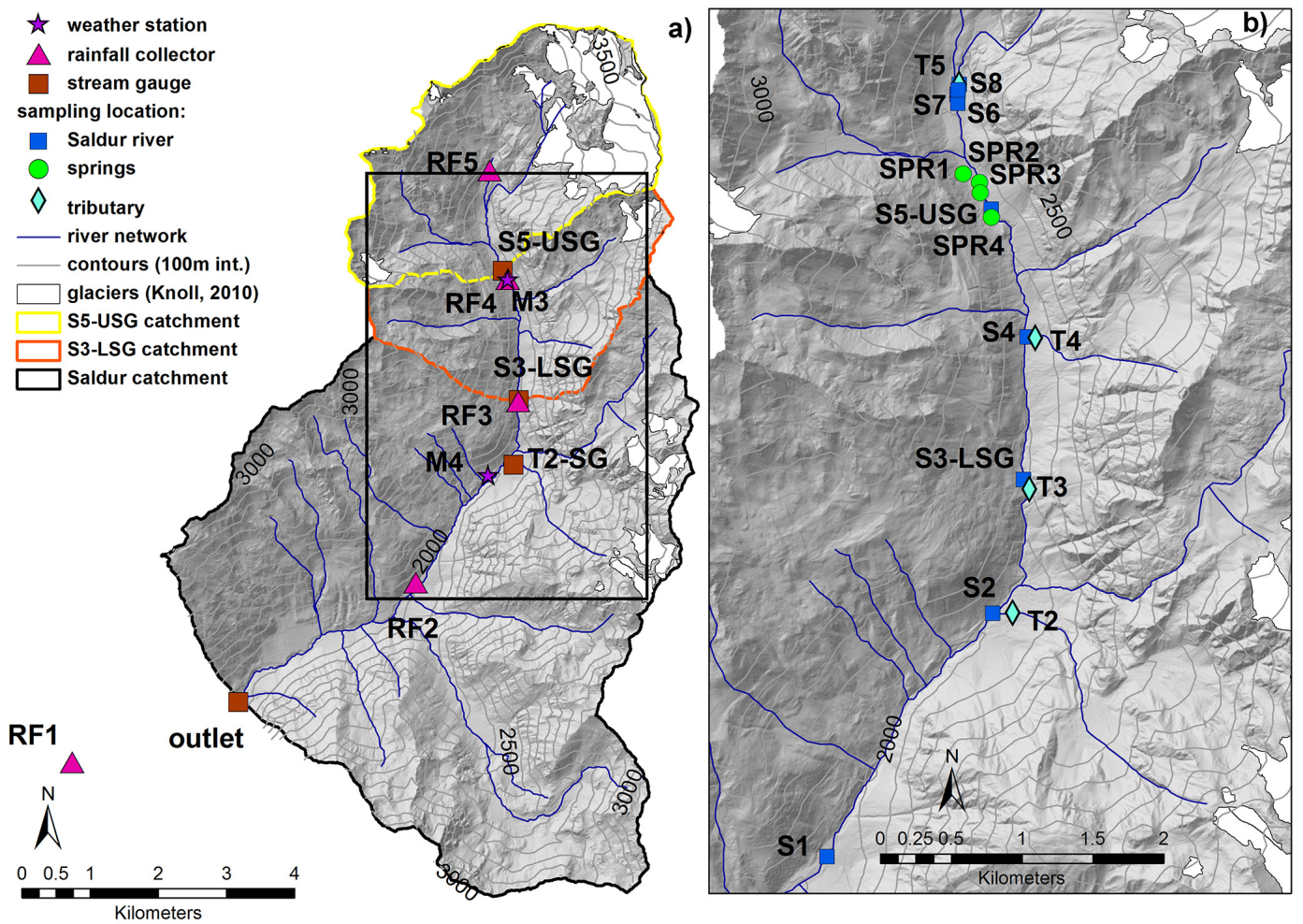

Figure 1. Map of the Saldur catchment with position of the rainfall collectors, stream gauges and weather stations (a); close-up showing the sampling locations for isotopic and EC analysis (b).

the higher elevations. Snow cover is almost complete at least over the upper three-quarters of the Saldur catchment (approximately above $2200 \mathrm{~m}$ a.s.l.) until late April-early May, when the melting season begins. Typically, at the end of June-early July snow cover amounts to approximately $10 \%$ of the total catchment area, as revealed by snow surveys and snow cover estimations based on MODIS data (Notarnicola et al., 2013). Permafrost and rock glaciers are most likely present at elevations higher than 2600-2800 m a.s.1., depending on local conditions (Boeckli et al., 2012, see Table 1).

The Saldur River has a nivo-glacial regime, with minima recorded during the winter and maxima typically observed in late spring and early summer. The average winter discharge at the catchment outlet during the 2012-2013 winter period was around $0.38 \mathrm{~m}^{3} \mathrm{~s}^{-1}$ whereas during summer 2013 it was $3.99 \mathrm{~m}^{3} \mathrm{~s}^{-1}$. The highest discharge since the start of monitoring (May 2009) was measured during a melt event on 21 June 2013 and reached $25.9 \mathrm{~m}^{3} \mathrm{~s}^{-1}$, whereas the second highest peak was recorded during a rainfall event on 4 September 2011 and reached $18.2 \mathrm{~m}^{3} \mathrm{~s}^{-1}$. However, these values must be considered approximated due to the uncertainties of the rating curve at high discharge values (see Sect. 3).

Geologically, the Saldur catchment belongs to the Matsch Unit, located in the southern Ötztal-Stubai complex and characterized by three main tectonometamorphic events in the Variscan, Permian and Cretaceous periods. The base of the Matsch Unit belongs to the Vinschgau Shear Zone, that changes in the Schlinig fault. The Matsch Unit mainly consists of gneisses, mica gneisses and schists. The land cover within the catchment is dominated by bare rocks and bare soil $(47 \%)$, grassland $(38 \%)$ and forest $(10 \%)$ (based on CORINE90 maps). The main grass vegetation Nardion strictae represents mostly the vegetation type at the bottom of the upper valley while the shrub vegetation RhododendroVaccinion covers mostly the valley slope. Haplic Leptosol are present above the tree line (at $2300 \mathrm{~m}$ a.s.l.), while forests, especially on the north-facing slopes, are mainly characterized by Haplic Podsols. Managed meadows below $1800 \mathrm{~m}$ a.s.l. are mostly characterized by Distric Cambisols. Soil texture can be classified between loamy sand and sandy loam (Bertoldi et al., 2014). The upper catchment is poorly subjected to human pressure as only sparse cattle and sheep grazing is present up to $2400 \mathrm{~m}$ a.s.l. A small gravel road goes up to around $2220 \mathrm{~m}$ a.s.l. and a limited net of tracks crosses the middle and the upper part of the catchment. The study area is part of the research site Matsch/Mazia Valley, member of the European Long-Term Ecosystem Research Network. 
Table 1. Main morphometric properties of the sub-catchments considered in the study area.

\begin{tabular}{lrrrrrc}
\hline $\begin{array}{l}\text { Sub- } \\
\text { catchment }\end{array}$ & $\begin{array}{r}\text { Drainage } \\
\text { area } \\
\left(\mathrm{km}^{2}\right)\end{array}$ & $\begin{array}{r}\text { Glacierized } \\
\text { area } \\
(\%)^{*}\end{array}$ & $\begin{array}{c}\text { Area } \\
\text { with } \\
\text { rock } \\
\text { glacier } \\
(\%)^{* *}\end{array}$ & $\begin{array}{c}\text { Elevation } \\
\text { range } \\
(\mathrm{m} \text { a.s.1. })\end{array}$ & $\begin{array}{c}\text { Average } \\
\text { slope } \\
\left({ }^{\circ}\right)\end{array}$ & $\begin{array}{c}\text { Average } \\
\text { aspect }\end{array}$ \\
& \multicolumn{7}{c}{. } & & \\
\hline S1 & 35.0 & 11.6 & 3.7 & $1809-3725$ & 29.9 & $\mathrm{~S}$ \\
S2 & 27.4 & 14.9 & 3.2 & $2001-3725$ & 31.8 & $\mathrm{~S}$ \\
S3-LSG & 18.6 & 16.9 & 4.2 & $2151-3725$ & 34.8 & $\mathrm{E}$ \\
S4 & 15.4 & 20.4 & 4.4 & $2231-3725$ & 32.3 & $\mathrm{~S}$ \\
S5-USG & 11.2 & 26.1 & 4.9 & $2333-3725$ & 30.8 & $\mathrm{~S}$ \\
S6 & 7.6 & 36.8 & 2.2 & $2401-3725$ & 29.5 & $\mathrm{~S}$ \\
S7 & 7.5 & 37.3 & 2.3 & $2407-3725$ & 29.5 & $\mathrm{~S}$ \\
S8 & 5.4 & 51.1 & 0.0 & $2415-3725$ & 28.7 & $\mathrm{~W}$ \\
T1 & 10.2 & 0.0 & 3.6 & $1775-3280$ & 31.5 & $\mathrm{~S}$ \\
T2-SG & 17.5 & 0.9 & 0.2 & $2028-3316$ & 19.7 & $\mathrm{~W}$ \\
T3 & $<0.0$ & 0.0 & 0.0 & $2159-2434$ & 30.4 & $\mathrm{~W}$ \\
T4 & 1.22 & 0.0 & 0.0 & $2232-3296$ & 35.0 & $\mathrm{~W}$ \\
T5 & 1.8 & 2.2 & 9.4 & $2416-3460$ & 30.7 & $\mathrm{~S}$ \\
\hline Total & 61.7 & 6.6 & 3.5 & $1632-3725$ & 31.8 & $\mathrm{~S}$ \\
\hline
\end{tabular}

* after the South Tyrolean Glacier Inventory (Knoll, 2010); ${ }^{* *}$ after Boeckli et al. (2012).

\section{Materials and methods}

\subsection{Field measurements and sampling}

Hydro-meteorological data used in this study were collected in the middle and upper part of the Saldur catchment approximately from April 2011 to October 2013. Precipitation and temperature were measured every $15 \mathrm{~min}$ by two nonheated weather stations (Onset Corporation, USA), labelled M3 and M4 (Fig. 1) at 2332 and 1998 m a.s.l., respectively, managed by the Institute for Alpine Environment of EURAC. For data analysis, the average values from these stations were used. Winter precipitation in these stations was estimated using automatic recorded snow height data from a nearby station of the EURAC network in a wind-sheltered location at the same elevation of the M4 station, following the approach suggested by Mair et al. (2013).

Water stage in the main Saldur channel was recorded every $10 \mathrm{~min}$ through pressure transducers at the catchment outlet (1632 m a.s.l., station run by the Hydrographic Office of the Province of Bozen-Bolzano), and at two natural sections, laterally well confined by large immobile boulders, named Lower Stream Gauge (S3-LSG, $2150 \mathrm{~m}$ a.s.l.) and Upper Stream Gauge (S5-USG, 2340 m a.s.l.). The drainage area of these two sub-catchments is 18.6 and $11.2 \mathrm{~km}^{2}$, respectively (Table 1). Eighty-two (82) salt dilution discharge measurements were taken under different flow conditions, in a range of 0.58 to $4.5 \mathrm{~m}^{3} \mathrm{~s}^{-1}$, repeatedly during the 3 years. The geometry of the natural cross-sections was monitored over time and different flow rating curves, derived from the salt dilution measurements, were applied through the 3 years. Water stage was also measured on a tributary on the left side of the valley (T2-SG, $2027 \mathrm{~m}$ a.s.l., drainage area of $1.7 \mathrm{~km}^{2}$ ) but direct discharge measurements were not available to build a reliable flow rating curve. Thus, for tributary T2-SG, stream stage was used throughout the study.

Stable isotopes of water and EC were measured in rain water, stream water, groundwater, snow, snowmelt and ice melt. The majority of samples was collected between April and October of each monitoring year but occasional samples were also taken in winter, early spring and late fall, especially at the lowest sampling locations. Bulk precipitation was sampled at five locations at different elevations along a $1000 \mathrm{~m}$ gradient (Fig. 1 and Table 2) using a $5 \mathrm{~L}$ high-density plastic bottle with a $18.5 \mathrm{~cm}$ diameter funnel. A mosquito net was placed inside the funnel to prevent leaves, particles or insects falling into the sampler. Bottles were filled with $1.5 \mathrm{~cm}$ of mineral oil to prevent evaporation and isotopic fractionation, and replaced approximately every 45 days in 2011 and roughly monthly in 2012 and 2013. Stream water was manually sampled (grab samples) in the Saldur River at eight locations and in five tributaries between 1775 and $2415 \mathrm{~m}$ a.s.l. (Fig. 1 and Table 2). The tributaries were chosen to represent sub-catchments characterized by different hydro-geomorphological properties and size (Table 1).

Groundwater was sampled from four springs between 2334 and $2360 \mathrm{~m}$ a.s.l. on the right side of the valley (Fig. 1 and Table 2), named SPR1 to SPR4. SPR1 was located at the bottom of a hillslope. The water flow was relatively fast but stopped completely when the spring dried out in October 2011 and 2013. SPR2 was surrounded by rocks in a ponding area and the flow was very slow. SPR3 was located close 
Table 2. Number of rainfall, stream and spring samples and elevation of each sampling location. RF: rainfall; S: Saldur River; T: tributaries of the Saldur River; SPR: springs. Samples at RF1 and RF5 were not collected in 2011. Samples at T1 were collected only in 2012, and samples at T3 only in 2011. In 2013 no tributaries were sampled and samples from the main stream were collected only at four locations (S1, S3-LSG, S5-LSG, S8). Note that S7 is the confluence just downstream S8 and T5 but after a large flood event occurred on 4 September 2011 which modified the morphology of the upper part of the Saldur River, it was moved to S6.

\begin{tabular}{lcr}
\hline $\begin{array}{l}\text { Sampling } \\
\text { location }\end{array}$ & $\begin{array}{r}\text { Elevation } \\
\text { (m a.s.1.) }\end{array}$ & $\begin{array}{r}\text { Number of } \\
\text { samples }\end{array}$ \\
\hline RF1 & 1575 & 12 \\
RF2 & 1829 & 16 \\
RF3 & 2154 & 15 \\
RF4 & 2336 & 15 \\
RF5 & 2575 & 8 \\
S1 & 1809 & 66 \\
S2 & 2001 & 32 \\
S3-LSG & 2150 & 89 \\
S4 & 2231 & 20 \\
S5-USG & 2333 & 27 \\
S6 & 2401 & 8 \\
S7 & 2410 & 9 \\
S8 & 2415 & 23 \\
T1 & 1775 & 13 \\
T2-SG & 2027 & 32 \\
T3 & 2159 & 18 \\
T4 & 2242 & 21 \\
T5 & 2415 & 18 \\
SPR1 & 2360 & 15 \\
SPR2 & 2348 & 16 \\
SPR3 & 2342 & 16 \\
SPR4 & 2334 & 25 \\
\hline & &
\end{tabular}

to the stream and connected to it (water flowing from the spring evidently moved downslope towards the stream). Similarly, SPR4 emerged from sand sediment and flowed down to the stream. Samples of stream water and groundwater were collected on a monthly basis.

The snowpack was sampled by snow corers. Three snow pits were dug on 8 March 2012 (at 1998, 2185, and 2205 ma.s.1.) and two on 6 February 2013 (at 1998 and $2085 \mathrm{~m}$ a.s.l.). Two samples were taken from each layer in the snow pits directly with the sampling bottles. The samples were stored in portable coolers in the field, and left to melt in the lab at roughly $20^{\circ} \mathrm{C}$. Two samples from the same layers were mixed and analysed. Three samples of fresh snow were collected in the lower part of the catchment after two snowfalls in spring 2012. In this case, snow was sampled by means of $1 \mathrm{~L}$ plastic bags, stored in a cooler, then left to melt at roughly $20^{\circ} \mathrm{C}$. A few other snow cores were taken occasionally, in spring and summer, at other locations and higher elevations. Snowmelt was sampled by collecting water drip- ping from snow patches, residual winter snowpack, approximately between 2190 and $2815 \mathrm{~m}$ a.s.l. Furthermore, the integrated value of snowmelt during the spring was measured using plastic snowmelt lysimeters (Shanley et al., 2002), with an approximate collecting area of $1 \mathrm{~m}^{2}$, connected to a $20 \mathrm{~L}$ bucket by $1 \mathrm{~m}$ long plastic tube. A $2 \mathrm{~cm}$ layer of mineral oil was put in the bucket during the lysimeter installation to prevent evaporation. Two lysimeters were placed at S3-LSG and one at $2205 \mathrm{~m}$ a.s.l. in fall 2011 and two at 2205 and $2225 \mathrm{~m}$ a.s.l. in fall 2012. They were emptied in mid-May 2012 and at the beginning of June 2013, respectively. Ice melt was collected by sampling rivulets flowing on the surface of the glacier tongue, approximately at $2800 \mathrm{~m}$ a.s.l. Additionally, some samples of water slowly dripping from melting debris-covered ice (part of a disconnected glacier mass) were taken near the glacier snout. Throughout the paper, we refer to glacier melt and debris-covered ice melt to distinguish between the two types of ice melt sampling methods. Snowmelt and ice melt samples were taken occasionally during the summer and early fall of the three monitoring years. Overall, 598 water samples were taken during the observational periods. The position of all field instruments and rainfall, stream water and groundwater sampling locations is displayed in Fig. 1.

\subsection{Laboratory analysis}

All water samples were collected in $50 \mathrm{~mL}$ high-density plastic bottles with a double cap, leaving no headspace. The samples were stored in the dark at $4{ }^{\circ} \mathrm{C}$ before isotopic analysis. The isotopic composition of the water samples was determined at the Laboratory of Isotope and Forest Hydrology of the University of Padova (Italy), Department of Land, Environments, Agriculture and Forestry by an off-axis integrated cavity output spectroscope (model DLT-100 908-0008, Los Gatos Research Inc., USA). The analysis protocol and the procedure adopted to minimize the carry-over effect are described in Penna et al. (2010, 2012). The typical instrumental precision (average standard deviation of 2094 samples) is $0.5 \%$ ofor $\delta^{2} \mathrm{H}$ and $0.08 \%$ for $\delta^{18} \mathrm{O}$. EC was measured in the field using a portable conductivity meter (WTW 3410 , WTW $\mathrm{GmbH}$, Germany) with a precision of $\pm 0.1 \mu \mathrm{S} \mathrm{cm}^{-1}$.

\subsection{Data analysis}

In order to identify the origin of the air masses that determine precipitation on the study area, and to better identify the endmembers for runoff we computed the deuterium-excess (dexcess) for each sample, defined as (Dansgaard, 1964)

$d-$ excess $=\delta^{2} \mathrm{H}-8 \delta^{18} \mathrm{O}$.

Low d-excess values indicate that evaporation fractionation has occurred, and this leads to a change in the slope of the relationship between $\delta^{18} \mathrm{O}$ and $\delta^{2} \mathrm{H}$. The d-excess represents the intercept of the linear fit line between $\delta^{18} \mathrm{O}$ and $\delta^{2} \mathrm{H}$ data 
in precipitation at the global scale, named global meteorological water line (GMWL, Craig, 1961) and defined as

$\delta^{2} \mathrm{H}(\% \circ)=8 \delta^{18} \mathrm{O}+10$.

The d-excess in precipitation is related to humidity and temperature at the moisture source (Dansgaard, 1964) and therefore is useful to infer the origin of water vapour that determines precipitation in the study area (Cui et al., 2009; Wassenaar et al., 2011; Hughes and Crawford, 2013). In southwestern Europe, precipitation data that show d-excess close to that of the GMWL typically indicate an Atlantic origin of air masses whereas higher d-excess may reflect the influence of water vapour coming from the Mediterranean basin, for which the local Mediterranean meteoric water line (MMWL) is valid (Gat and Carmi, 1970):

$\delta^{2} \mathrm{H}(\% \circ)=8 \delta^{18} \mathrm{O}+22$.

The identification of the end-members to surface and subsurface runoff was performed by using d-excess coupled to $\delta^{2} \mathrm{H}$ data of rainfall, glacier melt and snowmelt, as well as of the streams and springs, and an end-member plot was built.

The computation of the snowmelt contribution to groundwater recharge was performed by using a simple twocomponent separation model (Pearce et al., 1986), based on water and tracer mass balance, as follows:

$Q_{1}=Q_{2}+Q_{3}$

$Q_{1} C_{1}=Q_{2} C_{2}+Q_{3} C_{3}$

$Q_{2}=\left[\left(C_{1}-C_{3}\right) /\left(C_{2}-C_{3}\right)\right] \times Q_{1}$,

where $Q_{1}, Q_{2}$ and $Q_{3}$ represent three different water components (in this case, spring water, snowmelt and rainfall) and $C_{1}, C_{2}$ and $C_{3}$ represent their tracer concentrations. On the basis of Eq. (6), we quantified the percentage of snowmelt contribution to groundwater recharge (SNML \%) over the 3 study years using $\delta^{2} \mathrm{H}$ data, as follows (Earman et al., 2006; Zhang et al., 2009):

$\mathrm{SNMLT} \%=\left[\left(C_{\mathrm{SPR}-} C_{\mathrm{RF}}\right) /\left(C_{\mathrm{SNM}-} C_{\mathrm{RF}}\right)\right] \times 100$,

where $C_{\mathrm{SPR}}$ is the average isotopic composition of all samples collected from each spring over the three monitoring periods, $C_{\mathrm{RF}}$ is the volume-weighted average isotopic composition of the 23 rainfall samples collected at the locations RF4 and RF5 (the ones closest and upstream the selected springs, Table 2 and Fig. 1) and $C_{\mathrm{SNM}}$ is the average isotopic composition of 16 snowmelt samples collected from melting snow patches at elevations higher than those of the springs. Similarly, we assessed the seasonal contribution of snowmelt to each spring for each sampling date in 2012 and 2013 (2011 was excluded due to the low number of snowmelt samples available). In this case, $C_{\mathrm{SPR}}$ is the isotopic composition of the spring water sample collected on a certain day, $C_{\mathrm{RF}}$ is the volume-weighted average isotopic composition of the rainfall samples collected at the locations RF4 and RF5 during

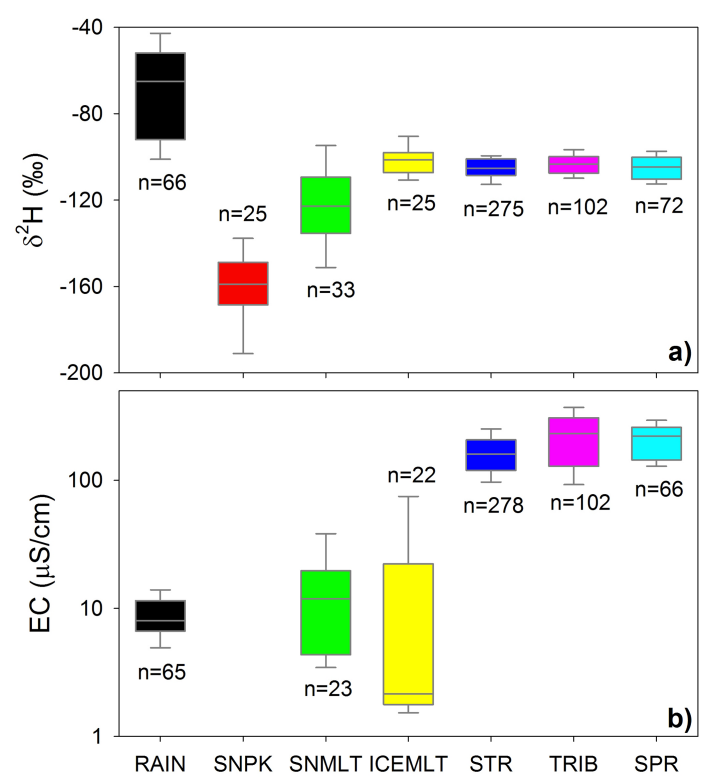

Figure 2. Box-plot for $\delta^{2} \mathrm{H}$ (a) and EC (b) of all water samples collected in this study. The whiskers represent the 10th and 90th percentiles, the box limits indicate the 25 th and 75 th percentiles and the line within the box marks the median. Legend: RAIN: rainfall; SNPK: winter snowpack and three samples of fresh snowfall; SNMLT: snowmelt (from patches of old snow and from snowmelt samplers); ICEMLT: ice melt (glacier melt and debris-covered ice); STR: main stream; TRIB: tributaries; SPR: springs. EC data of the snowpack (SNPK) were not available.

the period previous to the sampling day, and $C_{\mathrm{SNM}}$ is the (average) isotopic composition of the snowmelt sample(s) collected on that day. The $70 \%$ uncertainty in the separation of the two components was estimated through the method suggested by Genereux (1998) that takes into account the difference between the isotopic composition of the components and the variability (expressed by the standard deviation) of the isotopic composition of each component. The smaller the difference and the larger the variability, the higher the uncertainty.

Given the covariance between $\delta^{2} \mathrm{H}$ and $\delta^{18} \mathrm{O}$ values of all samples, we report in the paper only $\delta^{2} \mathrm{H}$ values in cases where information deriving from both isotopes were redundant.

\section{Results and discussion}

\subsection{Tracer concentration in different waters}

The different waters sampled in the Saldur catchment during this study showed a marked variability in tracer concentration (Fig. 2). Over the entire data set, $\delta^{2} \mathrm{H}$ values ranged from -26.1 to $-202.0 \%$ and EC ranged from 1 to $461 \mu \mathrm{S} \mathrm{cm}^{-1}$. Rainfall and winter snowpack samples were characterized by the most positive and the most negative isotopic compo- 
sition, respectively. Overall, snowmelt had values between rainfall and snowpack whereas ice melt was more enriched with heavy isotopes. Stream water from the main stream and the tributaries, and groundwater from the springs had statistically different isotopic compositions (Kruskal-Wallis test significant at 0.05 level).

The median EC of rainfall (Fig. 2b) was lower than the EC typically measured in precipitation both in urban catchments (e.g. Pellerin et al., 2008; Meriano et al., 2011) and in other mountain catchments in more natural settings (e.g. Lambs, 2000; Zabaleta and Antigüedad, 2013). Low EC in rainfall indicates low concentration of solutes and suggests a small or negligible influence of air masses coming from the Mediterranean Sea basin, rich in salts and therefore characterized by higher EC (see also Sect. 4.2). The median EC of snowmelt (from patches of old snow and from the snowmelt lysimeters as a whole) and ice melt (glacier melt and debris-covered ice melt as a whole) was also low and very low, respectively. Thus, the isotopic composition of rainfall, snowmelt and ice melt allowed for a clearer separation of these endembers than EC. The median EC of stream water in the tributaries and groundwater was similar and higher than that of the Saldur River which clearly reflected the contribution of low EC snowmelt and ice melt to streamflow (Sect. 4.7). EC samples of stream water and groundwater showed statistical differences even more marked than those shown by $\delta^{2} \mathrm{H}$ data (Kruskal-Wallis test significant at 0.01 level). This reflects the fact that all expected water sources contributing to streamflow during rainfall events and melting periods (rainfall, snowmelt and ice melt) had low values of EC but contrasting isotopic composition that compensated when mixed in the Saldur River.

\subsection{Isotopic composition of rainfall}

The linear relationship between $\delta^{18} \mathrm{O}$ and $\delta^{2} \mathrm{H}$ composition of rainfall data collected at different elevations in the Saldur catchment defined a local meteorological water line (LMWL), expressed as (Fig. 3)

$\delta^{2} \mathrm{H}(\%)=8.1 \delta^{18} \mathrm{O}+10.3, \quad R^{2}=0.99, \quad n=66$.

This relationship is slightly different from the LMWL of northern Italy (Longinelli and Selmo, 2003; Longinelli et al., 2008, Table 3) and also from the LWML found by Chiogna et al. (2014) for a station at $1176 \mathrm{~m}$ a.s.l. in a glacierized Alpine catchment between the Ortles-Cevedale and the Adamello-Presanella massifs (northern Italy, approximately $44 \mathrm{~km}$ south in a straight line from the Saldur catchment, Table 3). Conversely, the LMWL in the Saldur catchment is quite similar to the one derived at the highest elevation (2731 m a.s.l.) reported by Chiogna et al. (2014) in similar climatic conditions (Table 3 ). It is evident that the slope of the Saldur LMWL (8.1) is higher than that of the other northern Italian sites at lower elevations (7.7 and 7.6, Table 3), but approximately the same as that in a mountain region at higher elevation (8.0, Table 3). More interestingly, both the slope and the d-excess of the Saldur LMWL are nearly identical to those of the GMWL (Eq. 2) and d-excess is noticeably different from that of the MMWL (Eq. 3). Although a full comparison among these relationships cannot be made because the LMWL at our site did not include samples collected during the winter, this reveals that precipitation (at least during late spring, summer and early fall of the three observation years) in the Saldur area, and likely in other left-side lateral valleys of the Upper Vinschgau valley, was predominantly originated by air masses developing on the Atlantic Ocean, with limited influence by inflow of water vapour from the Mediterranean sea. This confirms what was indicated by the very low EC observed in rainfall (Sect. 4.1). Moreover, these observations are in agreement with the fact that the complex topography of South Tyrol leads to the coexistence of many different microclimates and precipitation patterns (Brugnara et al., 2012).

Figure 3 also highlights the clear and expected temperature-dependent seasonality (e.g. Wassenaar et al., 2011) with heavier isotopic values occurring during the summer, lighter values occurring during the fall and intermediate values generally occurring during the spring, and partially overlapping with the most negative summer samples and the most positive fall samples. In addition, we observed a marked altitude effect (Araguás-Araguás et al., 2000; inset of Fig. 3), recognized in almost all mountain ranges worldwide (Poage and Chamberlain, 2001). Particularly, the linear relationship between the average isotopic composition of rainfall samples and elevation in the Saldur catchment yielded an isotopic depletion rate of $-1.6 \%$ or $\delta^{2} \mathrm{H}$ and $-0.23 \%$ or $\delta^{18} \mathrm{O}$ per $100 \mathrm{~m}$ rise in elevation. This gradient is steeper than that found by Chiogna et al. (2014), and is gentler than that in the Kumaon Himalaya, India (Kumar et al., 2010), and in a snowmelt- and glacier melt-dominated Andean catchment, Chile (Ohlanders et al., 2013). However, the gradient is fully consistent with that in Kashmir Himalaya (Jeelani et al., 2013) and with the one reported by Longinelli et al. (2006) for an Alpine region in northwestern Italy.

Elevation played also a role on the spatial variability of d-excess in precipitation. Although the relationship was less strong than the one between elevation and $\delta^{2} \mathrm{H}$ and $\delta^{18} \mathrm{O}$ in rainfall, our data (not reported) showed that d-excess (the average of data available for all five sampling locations, $n=8$ ) increased roughly linearly by $0.2 \%$ per $100 \mathrm{~m}$ rise in elevation $\left(R^{2}=0.69, n=5\right.$, significant at 0.1 level). This effect was also reported for other mountain areas (Cui et al., 2009; Kumar et al., 2010; Jeelani et al., 2013). In some cases, the increase of d-excess with altitude was reported to be mainly present at high relative humidity (Gonfiantini et al., 2001; Windhorst et al., 2013) which is not the case of the study area. In the Saldur catchment, this effect may be attributed to higher relative humidity at higher elevations due to snow and ice melting which tends to enhance the kinetic fractionation process during evaporation (see Peng et al., 2004). 
Table 3. Local meteoric water lines (LMWL) reported by different authors for mountain sites in northern Italy.

\begin{tabular}{lll}
\hline Reference & Study area & LMWL \\
\hline $\begin{array}{l}\text { Longinelli and Selmo (2003); } \\
\text { Longinelli et al. (2008) }\end{array}$ & $\begin{array}{l}\text { Across four regions in northern Italy, between } 400 \\
\text { and 2125 m a.s.l. }\end{array}$ & $\delta^{2} \mathrm{H}(\% o)=7.7 \delta^{18} \mathrm{O}+9.4$ \\
\hline Chiogna et al. (2014) & $\begin{array}{l}\text { Vermigliana catchment, } \\
\text { northern Italy, at 1176 m a.s.l. }\end{array}$ & $\delta^{2} \mathrm{H}(\% o)=7.6 \delta^{18} \mathrm{O}+2.7$ \\
\hline Chiogna et al. (2014) & $\begin{array}{l}\text { Vermigliana catchment, } \\
\text { northern Italy, at 2731 m a.s.l. }\end{array}$ & $\delta^{2} \mathrm{H}(\% o)=8.0 \delta^{18} \mathrm{O}+7.8$ \\
\hline
\end{tabular}

Table 4. Parameters of the linear relationship between $\delta^{18} \mathrm{O}$ and $\delta^{2} \mathrm{H}$ for snowmelt, ice melt and snowpack samples presented in Fig. 4, and for all stream water (Saldur and tributaries) and groundwater samples.

\begin{tabular}{lrrrc}
\hline & $n$ & Slope & Intercept & $R^{2}$ \\
\hline Snowmelt (from spring and summer snow patches) & 23 & 8.1 & 9.7 & 0.99 \\
Snowmelt (from snowmelt samplers) & 10 & 7.9 & 4.7 & 0.99 \\
Ice melt (rivulets on the glacier surface) & 16 & 7.7 & 7.8 & 0.98 \\
Ice melt (melting debris-covered ice) & 9 & 7.6 & 5.4 & 0.92 \\
Winter snowpack & 22 & 8.2 & 15.0 & 0.97 \\
Stream water (Saldur River) & 274 & 7.9 & 9.5 & 0.92 \\
Stream water (tributaries) & 102 & 6.5 & -10.5 & 0.92 \\
Groundwater & 72 & 7.2 & -1.9 & 0.95 \\
\hline
\end{tabular}

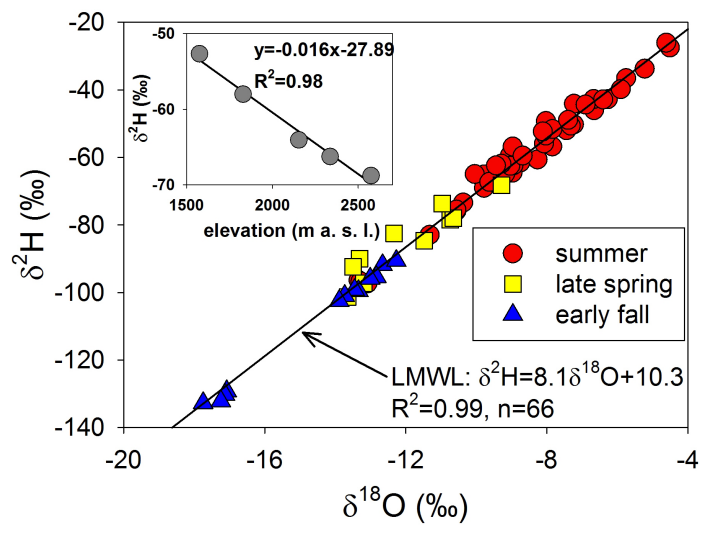

Figure 3. Relationship between $\delta^{18} \mathrm{O}$ and $\delta^{2} \mathrm{H}$ values of rainfall samples. Inset: relationship between elevation and average $(n=8)$ $\delta^{2} \mathrm{H}$ in precipitation data from the bulk rainfall collectors. For the inset plot, only data available for all five locations were averaged. Both correlations are statistically significant at the 0.01 level.

\subsection{Isotopic composition of snow, snowmelt and ice melt}

Snow samples taken from the winter snowpack covered a broad isotopic range (Fig. 4), reflecting a wide variability in air temperature that may have occurred also during the winter. Moreover, snow samples plotted well on the LMWL (and therefore on the GMWL), as also confirmed by the slope and interception values very similar to those of the LMWL

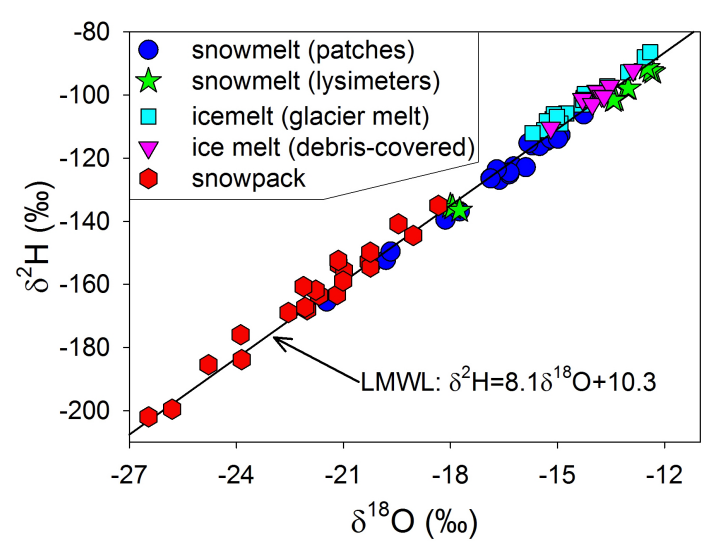

Figure 4. Relationship between $\delta^{2} \mathrm{H}$ and $\delta^{18} \mathrm{O}$ values of snowmelt, ice melt and snow.

(Table 4). This was also found for a set of snow-dominated catchments in Switzerland (Dietermann and Weiler, 2013) and indicates a similar geographical origin of precipitation during the winter with respect to the other seasons. However, we must mention that the range in the isotopic composition of snow samples was likely underestimated, due to the uncertainty associated with finding sampling locations representative for the isotopic signature of snowpack over the entire catchment. Indeed, in addition to altitude and seasonal effects, several other factors such as micro- and macro-topography, relocation of snow through wind drift and 
avalanches, and enrichment of heavy isotopes in upper layers of the snowpack depending on the sun exposure can contribute to significantly enhance the spatial and temporal variability of the isotopic composition of snowpack (Dietermann and Weiler, 2013). Samples collected from melting snow patches showed a wide isotopic range too (Fig. 4). This likely reflects the different elevations at which the samples were collected and, at the same time, the progressive seasonal isotopic enrichment that snowpack underwent during the melting process (Taylor et al., 2001; Lee et al., 2010). Meltwater samples of snow patches fell on the LMWL too (Fig. 4), and were characterized by values of slope and intercept very similar to those of the LMWL (Table 4), indicating no or negligible secondary fractionation effects due to evaporation during deposition and melting processes. Alternatively, this might also suggest a high consistency of isotopic fractionation as well as a temporal covariation of meltwater isotopic values at the catchment scale (Zhou et al., 2014). Winter- and spring-integrated snowmelt samples taken from the lysimeters also followed the LMWL but were slightly below the line (Fig. 4) and showed a slightly smaller slope and intercept (Table 4). Moreover, except for three samples, snowmelt samples collected from lysimeters were isotopically heavier than snowmelt samples collected from snow patches. This difference was related to some possible contamination from precipitation during the spring, relatively enriched in heavy isotopes. The three samples with more negative values were collected in spring 2012 from snow lysimeters located close to the stream at S3-LSG, in a zone where the valley is relatively narrow and direct sunlight is limited.

Ice melt samples generally plotted on the LMWL but, in accordance to Gooseff et al. (2006), the slopes and the intercepts of their $\delta^{18} \mathrm{O}-\delta^{2} \mathrm{H}$ relationships for both glacier melt and debris-covered ice melt were slightly smaller than those of the LMWL (Table 4). A comparison of the isotopic composition of glacier meltwater in the Saldur catchment with samples taken in other parts of the globe reveals the variability of dominant climatic conditions. Saldur glacier melt was more depleted compared to the Mafengu River, China (Yang et al., 2012), similar to the Ganga River catchment in the Himalayan foothills (Maurya et al., 2011) and in the Langtang and Dudh Kosi basins in Nepal Himalaya (Racoviteanu et al., 2013). However, it was heavier than that in the Wind River Range in the American Rockies (Cable et al., 2011) and a Central Andean catchment (Ohlanders et al., 2013) and, not surprisingly, much heavier than that found at the Imersuaq Glacier, West Greenland (Yde and Tvis Knudsen, 2004).

The isotopic range of glacier melt and debris-covered ice melt samples collected in the Saldur catchment was similar (Fig. 4). However, glacier melt typically showed higher d-excess but similar variability of d-excess compared to debris-covered ice melt. This difference was likely associated with the aforementioned increase in d-excess with elevation (Sect. 4.2), since the rivulets sampled on the glacier surface originated at higher elevations compared to the debris- covered ice collected nearby the glacier snout. Moreover, the expected lower melt rate due to the debris coverage, compared to the melt occurring on the bare glacier surface, might have also determined secondary evaporation effects (confirmed by the slightly smaller slope compared to glacier melt, Table 4) contributing to the difference in d-excess between the two subsets. However, the most striking difference between the two types of ice melt samples lies in the much higher and more variable EC of meltwater derived from ice bodies covered by debris compared to the extremely low (almost distilled) and little-variable EC of glacier meltwater. This difference, reflecting the very high variability in EC of all ice melt samples (glacier melt and debris-covered ice melt, Fig. 2, panel b), was not unexpected considering the contact that the latter had with rocks and fine debris that could release salts thereby increasing the EC of meltwater.

\subsection{Isotopic composition of stream water and groundwater}

The isotopic composition of stream water showed a narrower range compared to rainfall, snowmelt and ice melt (Fig. 2a) indicating that waters originating from upstream sources mixed to give composite stream water (Dalai et al., 2002; Maurya et al., 2011). The slope of 7.9 of the $\delta^{18} \mathrm{O}-$ $\delta^{2} \mathrm{H}$ relationship of stream water in the Saldur River was similar to that of rainfall (Fig. 3) and especially to that of snowmelt (Table 4), indicating that these water sources underwent similar fractionation processes. In contrast, groundwater and stream water in the tributaries showed lower slopes of the $\delta^{18} \mathrm{O}-\delta^{2} \mathrm{H}$ relationship compared to the Saldur River waters and to rainfall samples (and therefore a departure from the LMWL, not shown) suggesting post-precipitation evaporation during the groundwater recharge process (Maurya et al., 2011), as discussed in Sect. 4.8.

\subsection{Identification of end-members}

The average values of $\delta^{2} \mathrm{H}$ plotted versus d-excess for all stream water and groundwater samples fell within a triangular domain defined by the average $\delta^{2} \mathrm{H}$ and d-excess (Machavaram et al., 2006) of rainfall, snowmelt and glacier melt (Fig. 5). Unfortunately, since we were able to measure rainfall intensity but not snowmelt and glacier melt intensity, only the $\delta^{2} \mathrm{H}$ and $\mathrm{d}$-excess values of rainwater samples were volume-weighted whereas snowmelt and glacier melt were not. This could affect mass balance computations but it is reasonable to assume that this would not change the general evidence provided by Fig. 5. Indeed, despite the large variability of measurements in all waters (evidenced by the long horizontal and vertical error bars), the mixing plot clearly reveals the importance of snowmelt and glacier melt as endmembers in the study catchment, playing therefore a major role on the runoff regimes of the Saldur River and of its tributaries, as also observed in other glacierized catch- 


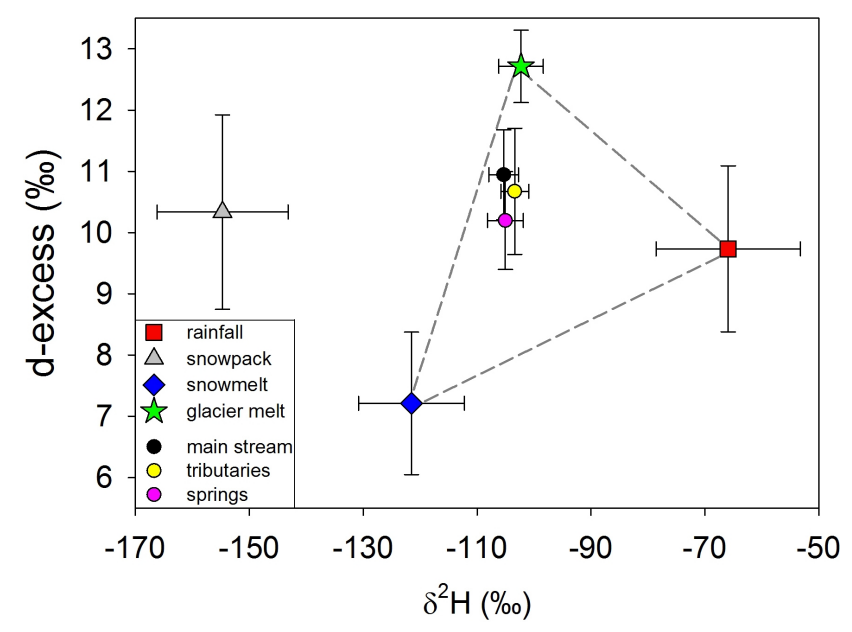

Figure 5. Mixing diagram between $\delta^{2} \mathrm{H}$ and d-excess of all average values of samples collected in the Saldur catchment. The error bars represent half of the standard deviation. The $\delta^{2} \mathrm{H}$ and d-excess composition of rainwater samples was volume-weighted whereas the snow, snowmelt and glacier melt composition was not. The snowpack is excluded from the mixing space because it is not a direct hydrological input.

ments (Zhang et al., 2009; Dahlke et al., 2013; Olhanders et al., 2013). However, it must be mentioned that we normally collected samples during no-rain periods, and therefore the contribution of rain water to the isotopic and EC composition of stream water and groundwater was likely underestimated. Although the error bars of samples within the triangular space largely overlapped, it is interesting to note that samples taken in the main stream were closer to the glacier melt end-member than the samples collected in the tributaries, and samples collected from the springs fell closer to the snowmelt end-member than stream water samples. This indicates, as expected, that glacier melt was a more important contributor to runoff in the main stream compared to the tributaries, and suggests an important role of snowmelt on groundwater recharge (Sect. 4.8). Snowpack samples were not included in the mixing plot because winter snowpack cannot be considered as a direct hydrological input.

\subsection{Temporal hydrological dynamics}

The three observational periods considered in this study showed different hydro-meteorological characteristics (Fig. 6). The average temperature over the 1 April-31 October period was similar for the 3 years $\left(6.7,6.5\right.$ and $6.3{ }^{\circ} \mathrm{C}$ for 2011, 2012 and 2013, respectively) but the temporal variability slightly differed. Most of all, cumulative precipitation was noticeably different, with 536, 467 and only $380 \mathrm{~mm}$ over the same period in 2011, 2012 and 2013, respectively. However, although 2013 was the driest year, streamflow and water stage at the gauging stations, especially at S5-USG, showed marked responses, suggesting important contribu- tions of meltwater. At the end of April-beginning of May, when the melting season started, streamflow in the main stream (Fig. 6g-1) and water stage in the tributary T2-SG (Fig. 6m-o) were typically low with values close to the winter baseflow (below $0.5 \mathrm{~m}^{3} \mathrm{~s}^{-1}$ at S5-USG, $1 \mathrm{~m}^{3} \mathrm{~s}^{-1}$ at S3-LSG and $5 \mathrm{~cm}$ at T2-SG). Then, streamflow noticeably increased during the warmer months (June-August) up to $3-4 \mathrm{~m}^{3} \mathrm{~s}^{-1}$ at S5-USG, $6-7 \mathrm{~m}^{3} \mathrm{~s}^{-1}$ at S3-LSG and 25-30 $\mathrm{cm}$ at T2-SG, and started to recede in September, reflecting the combination of limited snow cover and incoming radiation too small to produce important melt. Additionally, streamflow showed a marked diurnal variability (Jost et al., 2012; Uhlmann et al., 2013), particularly in the main stream and slightly less evident in the tributary, with clear fluctuations dependent on daily temperature oscillations that triggered the release of meltwater to the stream network (Fig. 6d-o).

At the seasonal scale, the melting dynamics seemed to override the role of rainfall on streamflow variability. Typical rainfall events were characterized by daily cumulative amounts of less than $10 \mathrm{~mm}$ that produced small streamflow response and limited sediment transport (Mao et al., 2014). However, the highest streamflow peaks were associated with relatively intense rainfall events. For example, $19.6 \mathrm{~mm}$ of rain fell in $4 \mathrm{~h}$ on 4 September 2011 and produced hourly streamflow peaks of $5.3 \mathrm{~m}^{3} \mathrm{~s}^{-1}$ at S5-USG, $8.0 \mathrm{~m}^{3} \mathrm{~s}^{-1}$ at S3LSG and a water stage peak of $37 \mathrm{~cm}$ at T2-SG, observed almost simultaneously at all three gauging locations.

\subsection{Spatio-temporal dynamics of tracer concentration in stream water and groundwater}

\subsubsection{Temporal variability of stream water and groundwater $\mathrm{EC}$ and $\delta^{2} \mathrm{H}$}

The isotopic composition of stream water (Fig. $6 \mathrm{~g}-\mathrm{O}$ ) did not reflect the seasonal variation of rainfall isotopic composition, with the less negative values occurring during the warmest periods (Sect. 4.2) but tended to mirror it (Jeelani et al., 2013). Indeed, the samples collected in the Saldur River and its selected tributaries revealed that during the late spring and the beginning of the summer (June-July) $\delta^{2} \mathrm{H}$ in stream water was relatively depleted in heavy isotopes (ranging approximately between -115 and $-110 \%$ ), then increased during mid-late summer to values close to the baseflow isotopic composition (Fig. 6). Similarly, EC was relatively high before the beginning of the melting period (up to approximately $250 \mu \mathrm{S} \mathrm{cm}^{-1}$ at S3-LSG), then decreased below $100 \mu \mathrm{S} \mathrm{cm}^{-1}$ during the melting season and increased to background values in mid-late October (Fig. 6). Given the very low EC and the significantly more negative values of snowmelt and ice melt compared to rainfall (Fig. 2), the general pattern suggests a remarkable contribution of meltwater to runoff in the Saldur catchment, confirming the results of the end-member mixing analysis (see Fig. 5 and Sect. 4.7.3). 

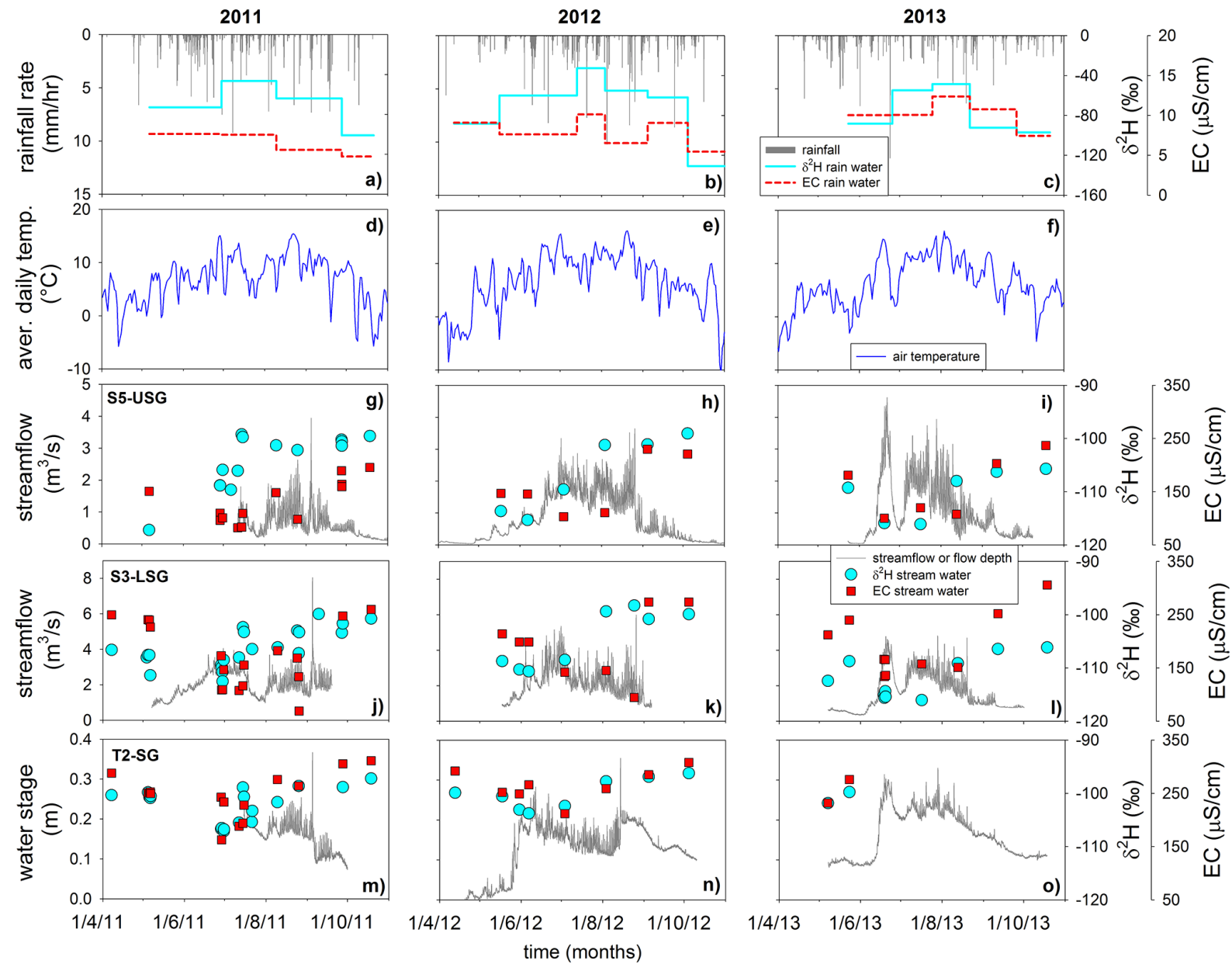

Figure 6. Top row panels (a-c): hourly time series of precipitation (average of values from M3 and M4), and $\delta^{2} \mathrm{H}$ and EC in bulk precipitation (average of values from RF2, RF3 and RF4). Second row panels (d-f): daily average temperature (average of values from M3 and M4). Middle row panels $(\mathbf{g}-\mathbf{i})$ : hourly time series of streamflow at S5-USG, and $\delta^{2} \mathrm{H}$ and EC of stream water. Fourth row panels (j-l): hourly time series of streamflow at S3-LSG, and $\delta^{2} \mathrm{H}$ and EC of stream water. Bottom row panels $(\mathbf{m}-\mathbf{o})$ : hourly time series of water height at T2-SG, and $\delta^{2} \mathrm{H}$ and $\mathrm{EC}$ of stream water. On five occasions in 2011 multiple samples were taken within 1 day at S3-LSG; only samples taken in the morning, at peak flow and before sunset are shown in (j)-(I). All panels refer to the period between 1 April and 31 October, when the majority of water samples was collected.

This trend was also revealed by the $\delta^{2} \mathrm{H}$ and $\mathrm{EC}$ of four locations along the Saldur River, three tributaries and the four selected springs (Fig. 7). We show here data from the Saldur locations where we collected samples approximately monthly during all three monitoring years, and from the three tributaries for which we have the most numerous measurements. There was an overall pattern of more negative isotopes and relatively low EC at the beginning and at the peak of the melting season. Analogously, less negative isotopes and higher EC were observed at the end of the season. Overall, this pattern was temporally consistent for stream water, both in the main stream and in the tributaries, and for groundwater. The increasing trend in isotopic composition and EC of the springs and the tributaries (generally with a negligible glacierized area compared to that of the main stream subcatchments, see Table 1) likely reflects the decreasing con- tribution of snowmelt over the season. Isotopes in the Saldur River in August 2013 (Fig. 7a) were noticeably less negative compared to the previous sampling time and disagreed with patterns showed by the isotopic composition of the springs (Fig. 7c). One reason for this difference could be related to the lagged arrival of the snowmelt contribution to the springs but this should be verified by means of additional data and possibly modelling application.

\subsubsection{Spatial variability of stream water and groundwater $\mathbf{E C}$ and $\delta^{2} \mathbf{H}$}

The consistency of temporal patterns across the different locations was particularly remarkable for the Saldur River locations and for springs SPR1-3 (Fig. 7a and c, respectively). Overall, location S8, higher in elevation and closer to the 

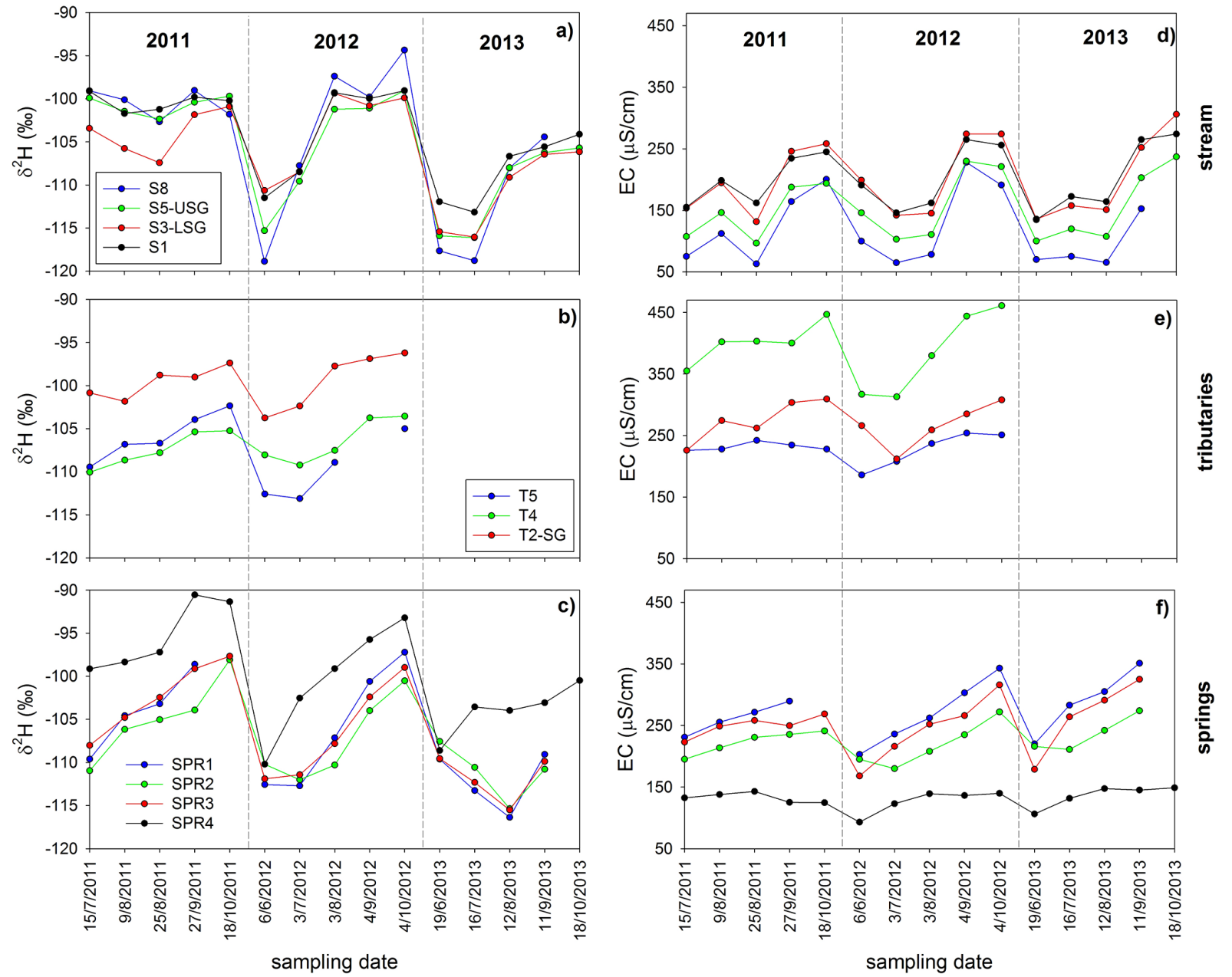

Figure 7. Inter-annual variability of isotopic composition and EC of stream water and groundwater for four locations in the Saldur River for which data were available for all three monitoring years (a and $\mathbf{d})$; the three tributaries for which the most measurements were available (b and $\mathbf{e}$ ); and the four springs (c and f) for sampling days in 2011, 2013 and 2013. Note that the spacing on the $x$-axis is not proportional to the temporal distance between the sampling dates.

glacier snout (Table 2), showed the most extreme $\delta^{2} \mathrm{H}$ and the lowest EC likely because it was more directly influenced by meltwater inputs. S3-LSG and S1, the locations more downstream, showed the highest EC, due to the comparatively higher contribution of groundwater. However, S3-LSG was characterized by relatively more negative $\delta^{2} \mathrm{H}$ compared to S1 due to the inflow of the highly isotopically depleted tributary at location T4 (data not shown). SPR4 showed a clearly different isotopic composition and EC concentration and different patterns compared to the other three springs. So far, we do not have experimental data to explain these differences but a more detailed analysis of groundwater geochemical and microbiological composition at different locations in the Saldur catchment is in progress.

\subsubsection{Seasonal change in snowmelt and ice melt contribution to runoff}

Figure 8 shows a box-plot of the stream water isotopic composition of four selected sampling locations along the Saldur River (S1, S3-LSG, S5 and S8) for the months June to October. Stream water was relatively depleted in heavy isotopes in June, isotopically heavier and characterized by a large variability in July and slowly increasingly enriched in heavy isotopes in August, September and October (Fig. 8a). Interestingly, EC showed a different pattern, with low values and similar variability in June, July (slightly lower) and August and markedly higher distributions in September and October (Fig. 8a). Although this plot masks the inter-annual variability of tracer concentration and the number of samples is limited, the observation of the different dynamics of the two tracers gives some hints on the seasonal switch of the most important contributors to runoff of the Saldur River. 

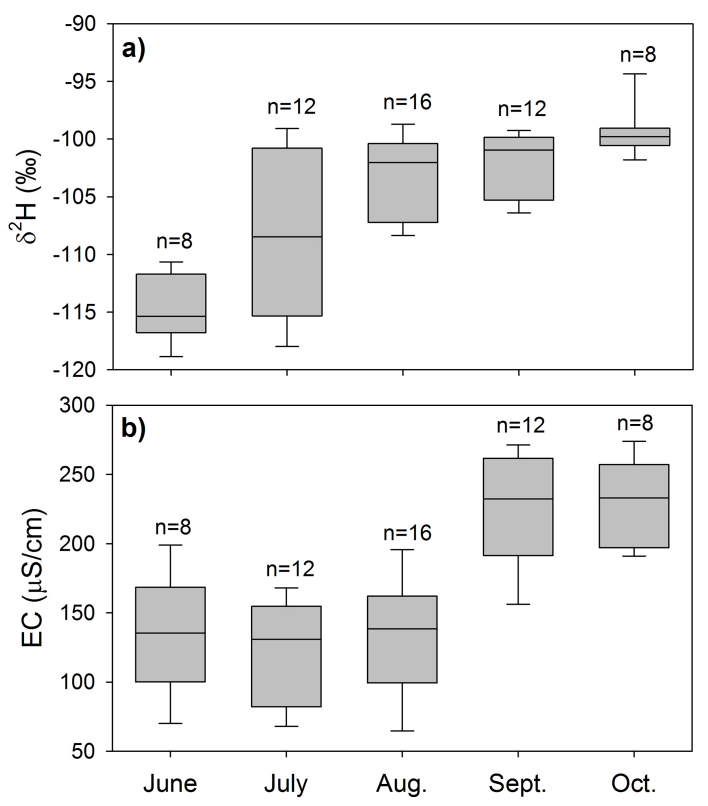

Figure 8. Box-plot of $\delta^{2} \mathrm{H}$ (a) and EC (b) of stream water data collected at the same time at the four selected locations along the Saldur River (S1, S3-LSG, S5 and S8) in 2011, 2012 and 2013 and grouped according to the sampling month. The whiskers represent the 10th and 90th percentiles, the box limits indicate the 25th and 75 th percentiles and the line within the box marks the median.

Indeed, the negative $\delta^{2} \mathrm{H}$ and low EC values found in June might reflect a major contribution of snowmelt, depleted in heavy isotopes and with low EC (Fig. 2). The even lower EC but less negative and more variable isotopes in July might reflect a mixed contribution of snowmelt and glacier melt that had extremely low EC but less negative isotopic composition (Fig. 2). The still low EC but the relatively heavier isotopes in August likely reflect a major contribution of glacier melt. Finally, the more enriched $\delta^{2} \mathrm{H}$ and the higher EC in September and October suggest a diminishing contribution of meltwater to the Saldur River, especially in October when the variability in the isotopic composition of stream water was very small.

The same conclusions can be drawn when looking at the spatio-temporal variability of tracer concentration at the same four selected locations along the main stream for different sampling days in 2013 , i.e. the year for which we have more data collected at approximately the same time of the day on different dates (Fig. 9). The low EC and the relatively heavier isotopes in stream water in August reflected particularly well the tracer composition of glacier melt (average $\delta^{2} \mathrm{H}=102.3 \%$, standard deviation $=7.8 \%$; average $\mathrm{EC}=2.1 \mu \mathrm{S} \mathrm{cm}^{-1}$, standard deviation $=0.7 \mu \mathrm{S} \mathrm{cm}^{-1}$ ) suggesting its dominant contribution to streamflow later in the melting season, when most of the catchment is typically snow-free. Moreover, the spatial pattern of tracer concentration along the stream was consistent among the different dates for EC (except for the decreasing value at S1 in Octo-

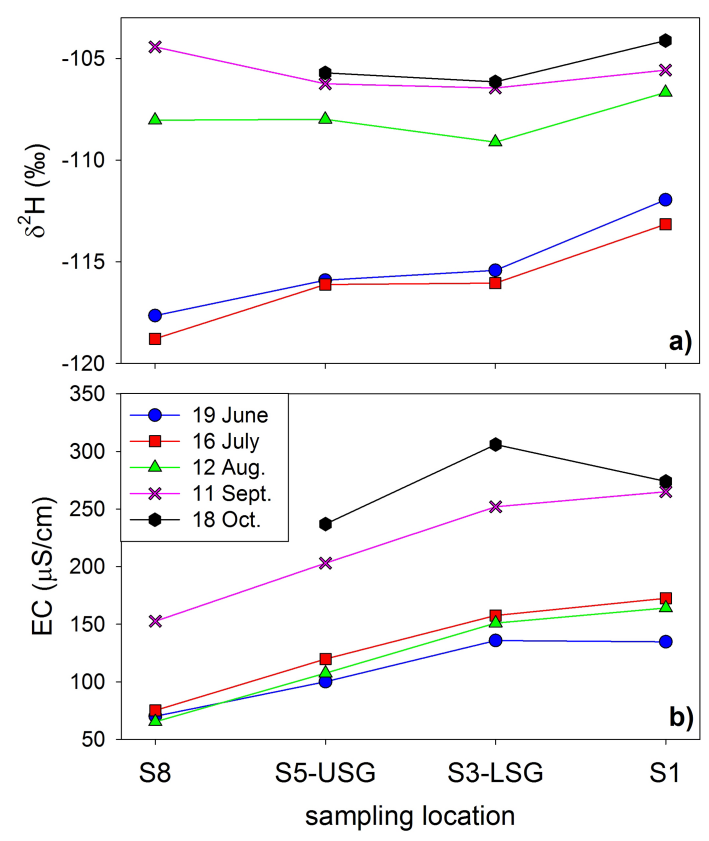

Figure 9. Isotopic composition and EC of stream water measured at selected locations along the Saldur River for different sampling days during the 2013 monitoring year. Sampling started at 15:00 LT at S8 and ended approximately at 17:30 at S1. On 18 October it was not possible to sample location S8, sampling started at S5-USG and was carried out between 13:45 and 14:45.

ber, Fig. 9b) and gentler but still fairly similar for $\delta^{2} \mathrm{H}$. This general temporal persistence of spatial patterns of tracer concentration indicates that the contribution of different water sources and of tributaries to the stream was continuous over time, i.e. all water sources and all tributaries, although carrying a possibly different isotopic and EC signature, gave continuous contributions over time, also revealing a good water mixing in the stream.

\subsection{Role of snowmelt on groundwater recharge}

The application of the isotope-based two-component separation model to spring water data (Eq. 7) allowed us to quantify the relative contribution of snowmelt to groundwater recharge, qualitatively assessed by the visual inspection of the temporal variability of tracer concentration in the selected springs (Sect. 4.7). Despite some inter-annual variability, snowmelt contributions to spring recharge were relatively low in June (Fig. 10), when the stream showed a snowmelt tracer signature (Fig. 8), and highest in July and August (Fig. 10), when most of the catchment area was snow-free. This indicates a relatively longer time for the snowmelt signal to appear in groundwater than in stream water, suggesting complex subsurface flow paths and long recharge times. The seasonal pattern was similar for the four springs, revealing a spatial consistency in the seasonal trend of groundwater recharge, at least at the small spatial scale of the four 


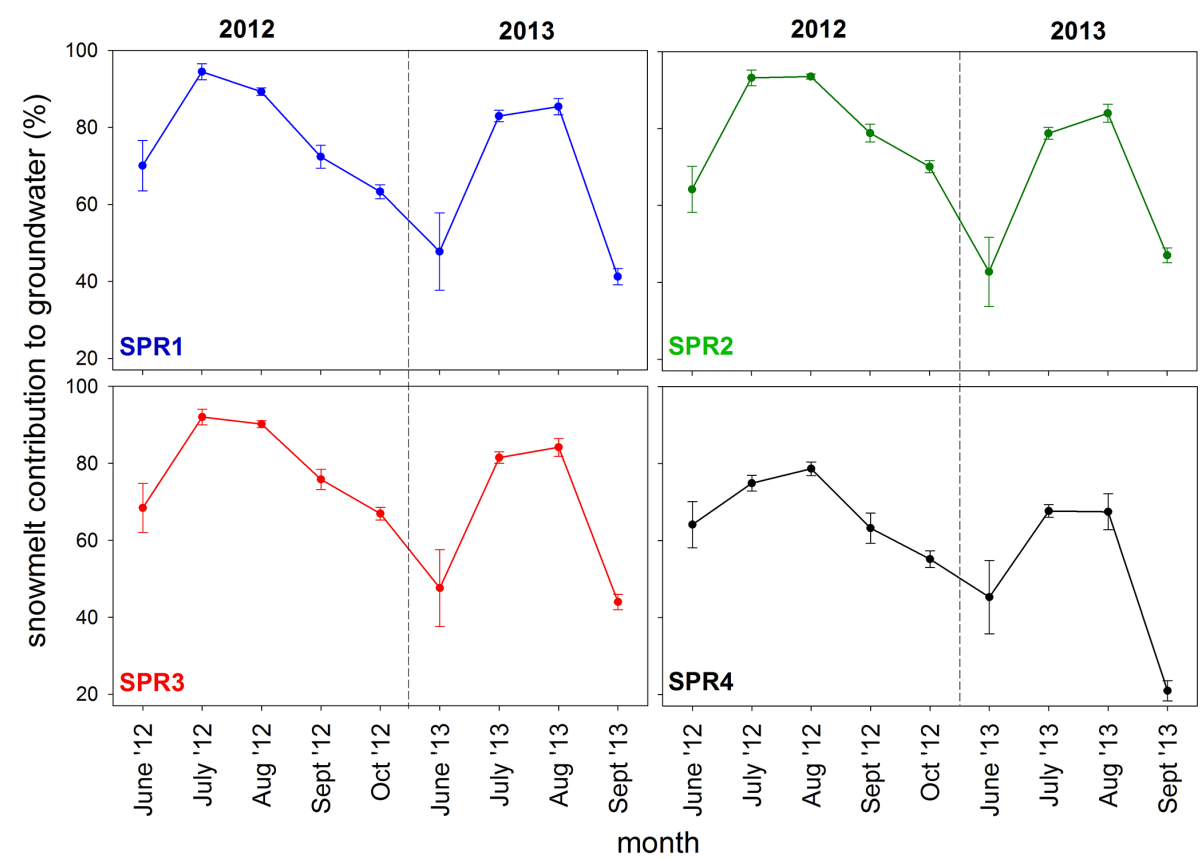

Figure 10. Snowmelt contribution to groundwater recharge based on $\delta^{2} \mathrm{H}$ data for different sampling times in 2012 and 2013 . The error bars indicate the \pm uncertainty at $70 \%$.

springs we investigated (Fig. 10). Our results also revealed that, over the three study years, snowmelt played a relevant role in groundwater composition in the Saldur River compared to rainfall, with overall contributions ranging from $58 \%( \pm 24 \%$ ) for SPR 4 to $72 \%$ ( $\pm 19 \%$ ) for SPR2 (Table 5 ). In this case, the average snowmelt used as an input for the separation model included all measurements taken over the 3 years in different months, therefore showing a broad range of isotopic values. As a consequence, the standard deviation was large. This explains the general higher uncertainties in the estimates of the overall snowmelt contribution to groundwater (Table 5) compared to the estimates of snowmelt contribution to groundwater calculated for different sampling times over the season (small vertical error bars in Fig. 10), for which the snowmelt input values of each sampling day derived from one individual sample or from the average of a few isotopically similar samples, therefore characterized by small standard deviations. Including ice melt data (both glacier and debris-covered ice melt) in the separation model gave inconsistent results, likely indicating the negligible contribution of ice melt to groundwater recharge. The very similar fractions among SPR1-3 and the different fractions compared to SPR4 agree, as expected, with the observed differences in the isotopic composition of the four springs (Fig. 7c and f). The comparatively minor role of summer precipitation in recharging groundwater is also confirmed by considering that the average isotopic composition of the springs was not consistent with the much more positive average isotopic composition of rainfall (Fig. 2a). When spring $\delta^{2} \mathrm{H}$ was plotted on a rainfall $\delta^{2} \mathrm{H}$ vs. elevation plot (not shown) to esti-
Table 5. Average (three years) snowmelt contribution to groundwater recharge based on $\delta^{2} \mathrm{H}$ data. The \pm uncertainty at $70 \%$ is reported after each estimate.

\begin{tabular}{cc}
\hline & $\begin{array}{c}\text { Snowmelt } \\
\text { contribution } \\
(\%)\end{array}$ \\
\hline SPR1 & $71 \pm 21$ \\
SPR2 & $72 \pm 19$ \\
SPR3 & $70 \pm 21$ \\
SPR4 & $58 \pm 24$ \\
\hline
\end{tabular}

mate the elevation of groundwater recharge (e.g. Jeelani et al., 2010) we obtained inconsistent results, i.e. the recharge elevation was found to be much higher than the highest peak in the study area. This demonstrates the noticeably greater contribution of snow precipitation compared to liquid precipitation. This is probably not surprisingly considering the low precipitation amounts that characterize the study area during the summer. However, these results are important for the development of a perceptual model of the hydrological functioning of the Saldur catchment. Moreover, these results are in agreement with the upper limit of the isotopic-based estimates of the role of snowmelt on groundwater recharge in the southwestern US (Earman et al., 2006) and confirm previous observations from other high-elevation catchments (Earman et al., 2006; Jeelani et al, 2010, 2013). 


\section{Limitations of the research and concluding remarks}

Spatially distributed samples of rainfall, snowmelt, ice melt, groundwater and stream water were collected over 3 years in the glacierized Saldur catchment in the eastern Italian Alps and analysed for stable isotopes of water and EC, allowing us to identify the main end-members and to explore the spatio-temporal variability of water sources. Data collection in such a high-elevation and complex terrain proved to be particularly challenging, and some issues arose. For instance, sampling at higher temporal frequency might have allowed us to explore some short-time responses in tracer concentration and detect some finer dynamics (e.g. Neal et al., 2013). Moreover, samples were not always taken at the same time of the day over the 3 years, preventing us from making comparisons on a more extended subset of data. More importantly, we were not able to sample permafrost and winter precipitation beside snowpack (we experienced snowfall collectors failures for two consecutive winters), likely yielding an incomplete overview of all potential end-members in the study catchment. Analogously, as mentioned above, the lack of sampling during rain periods probably provided an underestimation of the role played by rain water in the isotopic and EC composition of stream water.

Despite these limitations, our study corroborated preliminary observations (Penna et al., 2013) and provided new insights into the isotopic characterization of waters in highelevation Alpine basins, allowing us to take advantage of the enhanced tracer capability derived from the combined use of EC and stable isotopes of water for identifying end-members. Particularly, our results shed new light on the main sources of water contributing to runoff and their spatio-temporal variability, information that were still missing in glacierized areas of South-Tyrol and are still very limited for the entire southern Alps. From a methodological point of view, this research provided one of the largest isotopic databases in glacierized catchments that we are aware of, even larger than some very robust data sets recently published (e.g. Ohlanders et al., 2013; Chiogna et al., 2014). Furthermore, our study was the first one, as far as we know, to provide samples of EC and isotopic composition of actual glacier melt in the Italian Alps, i.e. meltwater flowing directly on the glacier surface and not water discharging from the glacier snout (possibly mixed with groundwater inflows). This allowed a better characterization of the tracer concentration of this end-member. Finally, the observation periods that spanned 3 years across various seasons allowed us to identify temporally invariant behaviours in tracer concentrations as well as to compare the inter-annual variability of water source dynamics, providing a broader idea of hydrological behaviours under different conditions.
In conclusions, the main results are the following:

- Rainfall samples delineated a LMWL remarkably similar to the GMWL, suggesting a predominantly oceanic origin of air masses in the study area. In addition to the seasonal effect, a clear altitude effect was observed for rainfall samples, with an isotopic depletion rate of $-1.6 \%$ for $\delta^{2} \mathrm{H}$ and $-0.23 \%$ for $\delta^{18} \mathrm{O}$ per $100 \mathrm{~m}$ rise in elevation.

- A marked variability in EC and isotopic composition of all sampled waters was evident, indicating a highly complex signature of water within the catchment. The combined signature provided by the two tracers yielded a clear distinction between input sources to the system, allowing us to identify snowmelt and glacier melt as the main end-members for stream water and groundwater, with a secondary role played by rainfall.

- The temporal dynamics of tracer concentrations and, particularly, the different dynamics of EC with respect to $\delta^{2} \mathrm{H}$ revealed a change in the main water source to the Saldur River runoff over the season, with snowmelt being the major contributor to streamflow during the first and central part of the melting period (June, July), whereas later in the summer, when most of the snow disappeared from the catchment, glacier melt contributed significantly. Despite such dynamics being well known in high-elevation catchments, their clear detection based on tracers is remarkable from a methodological perspective.

- The contribution of snowmelt to groundwater recharge, quantified by using an isotope-based two-component separation model, generally decreased during the season, varying between $93 \%( \pm 1 \%)$ in August and $21 \%( \pm 3 \%)$ in September. The overall contribution of snowmelt to groundwater over the 3 years ranged between $58 \%( \pm 24 \%)$ and $72 \%( \pm 19 \%)$, revealing the marked importance of snowmelt for subsurface water storage in the Saldur catchment.

Acknowledgements. This work was financially supported by the research projects "Effects of climate change on high-altitude ecosystems: monitoring the Upper Match Valley" (Foundation of the Free University of Bozen-Bolzano) and "EMERGE: Retreating glaciers and emerging ecosystems in the Southern Alps" (Dr. ErichRitter- und Dr. Herzog-Sellenberg-Stiftung im Stifterverband für die Deutsche Wissenschaft). Technical support was provided by the Dept. of Hydraulic Engineering and Hydrographic Office of the Autonomous Province of Bozen-Bolzano. The project "HydroAlp", financed by Autonomous Province of Bozen-Bolzano, partly supported the work of G. Bertoldi. G. Niedrist of EURAC is thanked for his work in maintaining the meteorological stations. Giulia Zuecco (University of Padova) is warmly thanked for the laser spectroscopy isotopic analysis. We thank Enrico Buzzi and 
Raffaele Foffa for support in field work. The first author is grateful to H. J. van Meerveld (University of Zurich) for helping and discussions during a field trip, and to James W. Kirchner (ETH, Zurich) for discussions on the preliminary results. Two anonymous reviewers are thanked for their constructive comments.

Edited by: F. Tian

\section{References}

Araguás-Araguás, L., Froehlich, K., and Rozanski, K.: Deuterium and oxygen-18 isotope composition of precipitation and atmospheric moisture, Hydrol. Process., 14, 13411355, doi:10.1002/1099-1085(20000615)14:8<1341::AIDHYP983>3.0.CO;2-Z, 2000.

Bertoldi, G., Della Chiesa, S., Notarnicola, C., Pasolli, L., Niedrist, G., and Tappeiner, U.: Estimation of soil moisture patterns in mountain grasslands by means of SAR RADARSAT 2 images and hydrological modelling, J. Hydrol., 516, 245-257, doi:10.1016/j.jhydrol.2014.02.018, 2014.

Boeckli, L., Brenning, A., Gruber, S., and Noetzli, J.: A statistical approach to modelling permafrost distribution in the European Alps or similar mountain ranges, The Cryosphere, 6, 125-140, doi:10.5194/tc-6-125-2012, 2012.

Brugnara, Y., Brunetti, M., Maugeri, M., Nanni, T., and Simolo, C.: High-resolution analysis of daily precipitation trends in the central Alps over the last century, Int. J. Climatol., 32, 14061422, doi:10.1002/joc.2363, 2012.

Cable, J., Ogle, K., and Williams, D.: Contribution of glacier meltwater to streamflow in the Wind River Range, Wyoming, inferred via a Bayesian mixing model applied to isotopic measurements, Hydrol. Process., 25, 2228-2236, doi:10.1002/hyp.7982, 2011.

Chiogna, G., Santoni, E., Camin, F., Tonon, A., Majone, B., Trenti, A., and Bellin, A.: Stable isotope characterization of the Vermigliana catchment, J. Hydrol., 509, 295-305, doi:10.1016/j.jhydrol.2013.11.052, 2014.

Craig, R.: Isotopic variations in meteoric waters, Science, 133, 1702-1703, 1961.

Cui, J., An, S., Wang, Z., Fang, C., Liu, Y., and Yang, H.: Using deuterium excess to determine the sources of high-altitude precipitation?: Implications in hydrological relations between sub-alpine forests and alpine meadows, J. Hydrol., 373, 24-33, doi:10.1016/j.jhydrol.2009.04.005, 2009.

Dahlke, H., Lyon, S., and Jansson, P.: Isotopic investigation of runoff generation in a glacierized catchment in northern Sweden, Hydrol. Process., 28, 1035-1050, doi:10.1002/hyp.9668, 2013.

Dalai, T. K., Bhattacharya, S. K., and Krishnaswami, S.: Stable isotopes in the source waters of the Yamuna and its tributaries: seasonal and altitudinal variations and relation to major cations, Hydrol. Process., 16, 3345-3364, doi:10.1002/hyp.1104, 2002.

Dansgaard, W.: Stable isotopes in precipitation, Tellus, 16, 436468, 1964.

Della Chiesa, S., Bertoldi, G., Niedrist, G., Obojes, N., Endrizzi, S., Albertson, J. D., Wohlfahrt, G., Hörtnagl, L., and Tappeiner, U.: Modelling changes in grassland hydrological cycling along an elevational gradient in the Alps, Ecohydrology, 7, 1453-1473, doi:10.1002/eco.1471, 2014.
Dietermann, N. and Weiler, M.: Spatial distribution of stable water isotopes in alpine snow cover, Hydrol. Earth Syst. Sci., 17, 26572668, doi:10.5194/hess-17-2657-2013, 2013.

Earman, S. and Campbell, A.: Isotopic exchange between snow and atmospheric water vapor: Estimation of the snowmelt component of groundwater recharge in the southwestern United States, J. Geophys., 111, 1-18, doi:10.1029/2005JD006470, 2006.

Earman, S., Campbell, A. R., Phillips, F. M., and Newman, B. D.: Isotopic exchange between snow and atmospheric water vapor: Estimation of the snowmelt component of groundwater recharge in the southwestern United States, J. Geophys. Res., 111, D09302, doi:10.1029/2005JD006470, 2006.

Galos, S. and Kaser, G.: The Mass Balance of Matscherferner 2012/13, project report, University of Innsbruck, Innsbruck, 2014.

Gat, J. R. and Carmi, I.: Evolution of the isotopic composition of atmospheric waters in the Mediterranean Sea area, J. Geophys. Res., 75, 3039-3048, 1970.

Genereux, D.: Quantifying uncertainty in tracer-based hydrograph separations, Water Resour. Res., 34, 915-919, doi:10.1029/98WR00010, 1998.

Gonfiantini, R., Roche, M., and Olivry, J.: The altitude effect on the isotopic composition of tropical rains, Chem. Geol., 181, 147167, doi:10.1016/S0009-2541(01)00279-0, 2001.

Gooseff, M. N., Lyons, W., McKnight, D. M., Vaughn, B. H., Fountain, A. G., and Dowling, C.: A stable isotopic investigation of a polar desert hydrologic system, McMurdo dry valleys, Antarctica, Arct. Antarct. Alp. Res., 38, 60-71, 2006.

Grah, O. and Beaulieu, J.: The effect of climate change on glacier ablation and baseflow support in the Nooksack River basin and implications on Pacific salmonid species protection and recovery, Climatic Change, 120, 657-670, doi:10.1007/s10584-013-0747y, 2013.

Hughes, C. E. and Crawford, J.: Spatial and temporal variation in precipitation isotopes in the Sydney Basin, Australia, J. Hydrol., 489, 42-55, doi:10.1016/j.jhydrol.2013.02.036, 2013.

Jeelani, G., Bhat, N. A., and Shivanna, K.: Use of $\delta^{18} \mathrm{O}$ tracer to identify stream and spring origins of a mountainous catchment: A case study from Liddar watershed, Western Himalaya, India, J. Hydrol., 393, 257-264, doi:10.1016/j.jhydrol.2010.08.021, 2010.

Jeelani, G., Kumar, U. S., and Kumar, B.: Variation of $\delta^{18} \mathrm{O}$ and $\delta \mathrm{D}$ in precipitation and stream waters across the Kashmir Himalaya (India) to distinguish and estimate the seasonal sources of stream flow, J. Hydrol., 481, 157-165, doi:10.1016/j.jhydrol.2012.12.035, 2013.

Jost, G., Moore, R. D., Menounos, B., and Wheate, R.: Quantifying the contribution of glacier runoff to streamflow in the upper Columbia River Basin, Canada, Hydrol. Earth Syst. Sci., 16, 849-860, doi:10.5194/hess-16-849-2012, 2012.

Kääb, A., Chiarle, M., Raup, B., and Schneider, C.: Climate change impacts on mountain glaciers and permafrost, Global Planet. Change, 56, vii-ix, doi:10.1016/j.gloplacha.2006.07.008, 2007.

Knoll, C.: A glacier inventory for South Tyrol, Italy, based on airborne laser-scanner data, Ann. Glaciol., 50, 46-52, 2010.

Koboltschnig, G. R. and Schöner, W.: The relevance of glacier melt in the water cycle of the Alps: the example of Austria, Hydrol. Earth Syst. Sci., 15, 2039-2048, doi:10.5194/hess-15-20392011, 2011. 
Kriegel, D., Mayer, C., Hagg, W., Vorogushyn, S., Duethmann, D., Gafurov, A., and Farinotti, D.: Changes in glacierisation, climate and runoff in the second half of the 20th century in the Naryn basin, Central Asia, Global Planet. Change, 110, 51-61, doi:10.1016/j.gloplacha.2013.05.014, 2013.

Kumar, U. S., Kumar, B., Rai, S. P., and Sharma, S.: Stable isotope ratios in precipitation and their relationship with meteorological conditions in the Kumaon Himalayas, India, J. Hydrol., 391, 1-8, doi:10.1016/j.jhydrol.2010.06.019, 2010.

Lambs, L.: Correlation of conductivity and stable isotope $\delta^{18} \mathrm{O}$ for the assessment of water origin in river system, Chem. Geol., 164, 161-170, 2000.

Lee, J., Feng, X., Faiia, A. M., Posmentier, E. S., Kirchner, J. W., Osterhuber, R., and Taylor, S.: Isotopic evolution of a seasonal snowcover and its melt by isotopic exchange between liquid water and ice, Chem. Geol., 270, 126-134, doi:10.1016/j.chemgeo.2009.11.011, 2010.

Longinelli, A. and Selmo, E.: Isotopic composition of precipitation in Italy: a first overall map, J. Hydrol., 270, 75-88, 2003.

Longinelli, A., Anglesio, E., and Flora, O.: Isotopic composition of precipitation in Northern Italy: reverse effect of anomalous climatic events, J. Hydrol., 329, 471-476, doi:10.1016/j.jhydrol.2006.03.002, 2006.

Longinelli, A., Stenni, B., Genoni, L., Flora, O., Defrancesco, C., and Pellegrini, G.: A stable isotope study of the Garda lake, northern Italy: Its hydrological balance, J. Hydrol., 360, $103-$ 116, 2008.

Longinelli, A., Stenni, B., and Genoni, L.: A stable isotope study of the Garda Lake, northern Italy: Its hydrological balance, J. Hydrol., 360, 103-116, doi:10.1016/j.jhydrol.2008.07.020, 2008.

Machavaram, M. and Whittemore, D.: Precipitation induced stream flow: An event based chemical and isotopic study of a small stream in the Great Plains region of the USA, J. Hydrol., 470 480, doi:10.1016/j.jhydrol.2006.04.004, 2006.

Machavaram, M. V., Whittemore, D. O., Conrad, M. E., and Miller, N. L.: Precipitation induced stream flow: An event based chemical and isotopic study of a small stream in the Great Plains region of the USA, J. Hydrol., 330, 470-480, doi:10.1016/j.jhydrol.2006.04.004, 2006.

Mair, E., Bertoldi, G., Leitinger, G., Della Chiesa, S., Niedrist, G., and Tappeiner, U.: ESOLIP - estimate of solid and liquid precipitation at sub-daily time resolution by combining snow height and rain gauge measurements, Hydrol. Earth Syst. Sci. Discuss., 10, 8683-8714, doi:10.5194/hessd-10-8683-2013, 2013.

Mao, L., Dell'Agnese, A., Huincache, C., Penna, D., Engel, M., Niedrist, G., and Comiti, F.: Bedload hysteresis in a glacier-fed mountain river: bedload hysteresis in a glacierfed mountain river, Earth Surf. Proc. Land., 39, 964-976, doi:10.1002/esp.3563, 2014.

Maurya, A. S., Shah, M., Deshpande, R. D., Bhardwaj, R. M., Prasad, A., and Gupta, S. K.: Hydrograph separation and precipitation source identification using stable water isotopes and conductivity: River Ganga at Himalayan foothills, Hydrol. Process., 25, 1521-1530, doi:10.1002/hyp.7912, 2011.

Meriano, M., Howard, K. W. F., and Eyles, N.: The role of midsummer urban aquifer recharge in stormflow generation using isotopic and chemical hydrograph separation techniques, J. Hydrol., 396, 82-93, doi:10.1016/j.jhydrol.2010.10.041, 2011.
Milner, A., Brown, L., and Hannah, D.: Hydroecological response of river systems to shrinking glaciers, Hydrol. Process., 77, 6277, doi:10.1002/hyp.7197, 2009.

Molini, A., Katul, G. G., and Porporato, A.: Maximum discharge from snowmelt in a changing climate, Geophys. Res. Lett., 38, 1-5, doi:10.1029/2010GL046477, 2011.

Neal, C., Reynolds, B., Kirchner, J. W., Rowland, P., Norris, D., Sleep, D., Lawlor, A., Woods, C., Thacker, S., Guyatt, H., Vincent, C., Lehto, K., Grant, S., Williams, J., Neal, M., Wickham, H., Harman, S., and Armstrong, L.: High-frequency precipitation and stream water quality time series from Plynlimon, Wales: an openly accessible data resource spanning the periodic table, Hydrol. Process., 27, 2531-2539, doi:10.1002/hyp.9814, 2013.

Notarnicola, C., Duguay, M., Moelg, N., Schellenberger, T., Tetzlaff, A., Monsorno, R., Costa, A., Steurer, C., and Zebisch, M.: Snow Cover Maps from MODIS Images at $250 \mathrm{~m}$ Resolution, Part 1: Algorithm Description, Remote Sensing, 5, 110 $126,2013$.

Ohlanders, N., Rodriguez, M., and McPhee, J.: Stable water isotope variation in a Central Andean watershed dominated by glacier and snowmelt, Hydrol. Earth Syst. Sci., 17, 1035-1050, doi:10.5194/hess-17-1035-2013, 2013.

Pasolli, L., Notarnicola, C., Bertoldi, G., Della Chiesa, S., Niedrist, G., Bruzzone, L., Tappeiner, U., and Zebisch, M.: Soil moisture monitoring in mountain areas by using high resolution SAR images: results from a feasibility study, Eur. J. Soil Sci., 65, 852864, doi:10.1111/ejss.12189, 2014

Pearce, A. J., Stewart, M. K., and Sklash, M. G.: Storm runoff generation in humid headwater catchments, 1 , where does the water come from?, Water Resour. Res., 22, 1263-1271, 1986.

Pellerin, B. and Wollheim, W.: The application of electrical conductivity as a tracer for hydrograph separation in urban catchments, Hydrol. Process., 22, 1810-1818, doi:10.1002/hyp.6786, 2008.

Pellerin, B. A., Wollheim, W. M., Feng, X., and Vörösmarty, C. J.: The application of electrical conductivity as a tracer for hydrograph separation in urban catchments, Hydrol. Process., 22, 1810-1818, doi:10.1002/hyp.6786, 2008.

Peng, H., Mayer, B., Harris, S., and Krouse, H. R.: A 10-year record of stable isotope ratios of hydrogen and oxygen in precipitation at Calgary, Alberta, Canada, Tellus B, 56, 147-159, 2004.

Penna, D., Stenni, B., Šanda, M., Wrede, S., Bogaard, T. A., Gobbi, A., Borga, M., Fischer, B. M. C., Bonazza, M., and Chárová, $\mathrm{Z}$.: On the reproducibility and repeatability of laser absorption spectroscopy measurements for $\delta^{2} \mathrm{H}$ and $\delta^{18} \mathrm{O}$ isotopic analysis, Hydrol. Earth Syst. Sci., 14, 1551-1566, doi:10.5194/hess-141551-2010, 2010.

Penna, D., Mao, L., Comiti, F., Engel, M., Dell'Agnese, A., and Bertoldi, G.: Hydrological effects of glacier melt and snowmelt in a high-elevation catchment, Bodenkultur, 64, 93-98, 2013.

Penna, D., Stenni, B., Šanda, M., Wrede, S., Bogaard, T. A., Michelini, M., Fischer, B. M. C., Gobbi, A., Mantese, N., Zuecco, G., Borga, M., Bonazza, M., Sobotková, M., Čejková, B., and Wassenaar, L. I.: Technical Note: Evaluation of between-sample memory effects in the analysis of $\delta^{2} \mathrm{H}$ and $\delta^{18} \mathrm{O}$ of water samples measured by laser spectroscopes, Hydrol. Earth Syst. Sci., 16, 3925-3933, doi:10.5194/hess-16-3925-2012, 2012. 
Poage, M. A. and Chamberlain, C. P.: Empirical relationships between elevation and the stable isotope composition of precipitation and surface waters: considerations for studies of paleoelevation change, Am. J. Sci., 301, 1-15, 2001.

Racoviteanu, A. E., Armstrong, R., and Williams, M. W.: Evaluation of an ice ablation model to estimate the contribution of melting glacier ice to annual discharge in the Nepal Himalaya: glacial contributions to annual streamflow in Nepal Himalaya, Water Resour. Res., 49, 5117-5133, doi:10.1002/wrcr.20370, 2013.

Shanley, J. and Kendall, C.: Controls on old and new water contributions to stream flow at some nested catchments in Vermont, USA, Hydrol. Process., 16, 589-609, doi:10.1002/hyp.312, 2002.

Shanley, J. B., Kendall, C., Smith, T. E., Wolock, D. M., and McDonnell, J. J.: Controls on old and new water contributions to stream flow at some nested catchments in Vermont, USA, Hydrol. Process., 16, 589-609, doi:10.1002/hyp.312, 2002.

Stewart, I.: Changes in snowpack and snowmelt runoff for key mountain regions, Hydrol. Process., 94, 78-94, doi:10.1002/hyp.7128, 2009.

Taylor, S., Feng, X., Kirchner, J. W., Osterhuber, R., Klaue, B., and Renshaw, C. E.: Isotopic evolution of a seasonal snowpack and its melt. Water Resour. Res., 37, 759-769, doi:10.1029/2000WR900341, 2001.

Uhlmann, B.: Modelling runoff in a Swiss glacierized catchment - Part II: daily discharge and glacier evolution in the Findelen basin, Int. J. Climatol., 33, 1301-1307, doi:10.1002/joc.3516, 2013.

Uhlmann, B., Jordan, F., and Beniston, M.: Modelling runoff in a Swiss glacierized catchment - Part II: daily discharge and glacier evolution in the Findelen basin in a progressively warmer climate, Int. J. Climatol., 33, 1301-1307, doi:10.1002/joc.3516, 2013.
Wassenaar, L. I., Athanasopoulos, P., and Hendry, M. J.: Isotope hydrology of precipitation, surface and ground waters in the Okanagan Valley, British Columbia, Canada, J. Hydrol., 411, 37-48, doi:10.1016/j.jhydrol.2011.09.032, 2011.

Windhorst, D., Waltz, T., Timbe, E., Frede, H.-G., and Breuer, L.: Impact of elevation and weather patterns on the isotopic composition of precipitation in a tropical montane rainforest, Hydrol. Earth Syst. Sci., 17, 409-419, doi:10.5194/hess-17-409-2013, 2013.

Yang, Y., Xiao, H., Wei, Y., Zhao, L., Zou, S., Yang, Q., and Yin, Z.: Hydrological processes in the different landscape zones of alpine cold regions in the wet season, combining isotopic and hydrochemical tracers, Hydrol. Process., 26, 1457-1466, doi:10.1002/hyp.8275, 2012.

Yde, J. C. and Tvis Knudsen, N.: The importance of oxygen isotope provenance in relation to solute content of bulk meltwaters at Imersuaq Glacier, West Greenland, Hydrol. Process., 18, 125139, doi:10.1002/hyp.1317, 2004.

Zabaleta, A. and Antigüedad, I.: Streamflow response of a small forested catchment on different timescales, Hydrol. Earth Syst. Sci., 17, 211-223, doi:10.5194/hess-17-211-2013, 2013.

Zhang, Y. H., Song, X. F., and Wu, Y. Q.: Use of oxygen-18 isotope to quantify flows in the upriver and middle reaches of the Heihe River, Northwestern China, Environ. Geol., 58, 645-653, doi:10.1007/s00254-008-1539-y, 2009.

Zhou, S., Wang, Z., and Joswiak, D. R.: From precipitation to runoff: stable isotopic fractionation effect of glacier melting on a catchment scale: catchment-scale isotopic fractionation effect of glacier melting, Hydrol. Process., 28, 3341-3349, doi:10.1002/hyp.9911, 2014. 